\title{
LEVEL II SCOUR ANALYSIS FOR BRIDGE 31 (HUNTTH00220031) on TOWN HIGHWAY 22, crossing BRUSH BROOK, HUNTINGTON, VERMONT
}

Open-File Report 97-673

Prepared in cooperation with

VERMONT AGENCY OF TRANSPORTATION and

FEDERAL HIGHWAY ADMINISTRATION

U.S. Department of the Interior

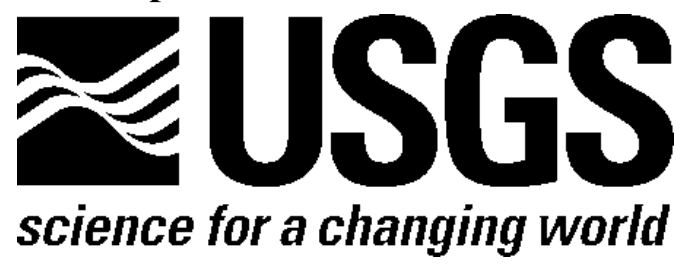


LEVEL II SCOUR ANALYSIS FOR

BRIDGE 31 (HUNTTH00220031) on

TOWN HIGHWAY 22, crossing

BRUSH BROOK,

HUNTINGTON, VERMONT

By ROBERT H. FLYNN AND JAMES R. DEGNAN

U.S. Geological Survey

Open-File Report 97-673

Prepared in cooperation with

VERMONT AGENCY OF TRANSPORTATION

and

FEDERAL HIGHWAY ADMINISTRATION 


\title{
U.S. DEPARTMENT OF THE INTERIOR BRUCE BABBITT, Secretary
}

\author{
U.S. GEOLOGICAL SURVEY \\ Mark Schaefer, Acting Director
}

For additional information write to:

District Chief

U.S. Geological Survey 361 Commerce Way

Pembroke, NH 03275-3718
Copies of this report may be purchased from:

U.S. Geological Survey

Branch of Information Services

Open-File Reports Unit

Box 25286

Denver, CO 80225-0286 


\section{CONTENTS}

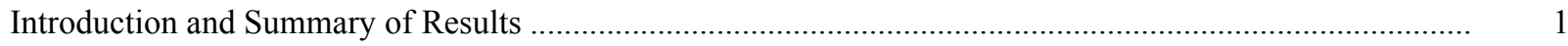

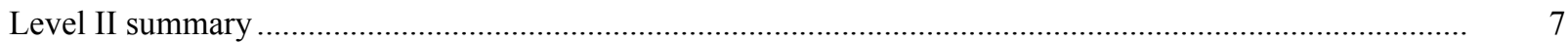

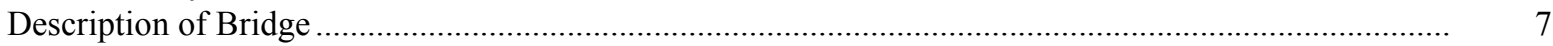

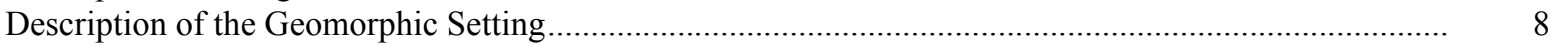

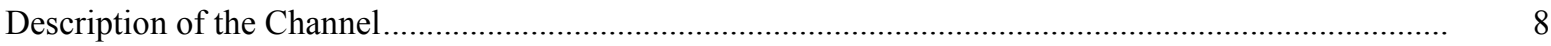

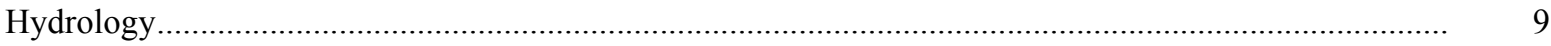

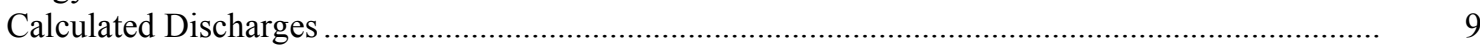

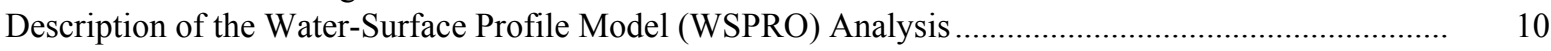

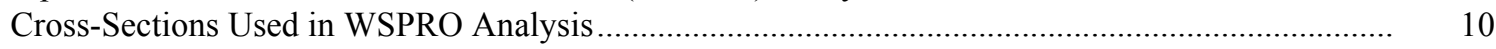

Data and Assumptions Used in WSPRO Model ...................................................................... 11

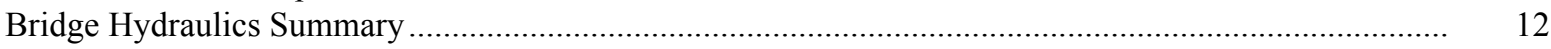

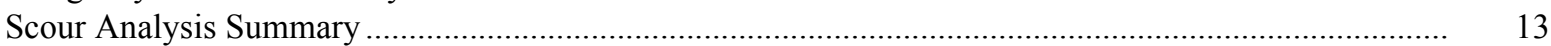

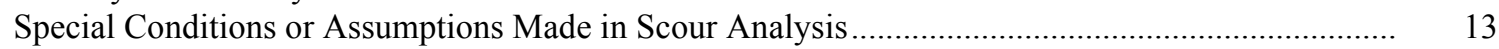

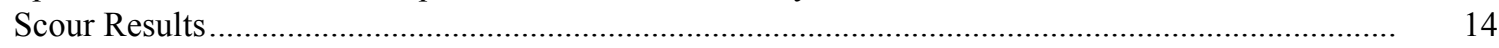

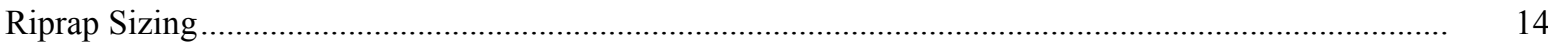

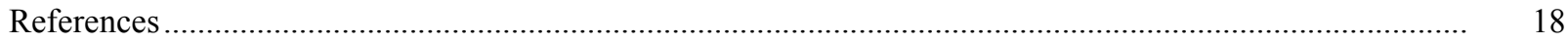

Appendixes:

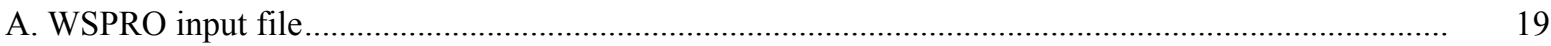

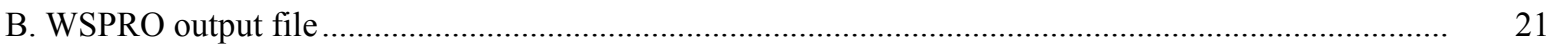

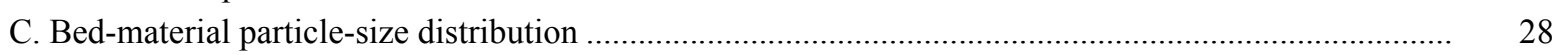

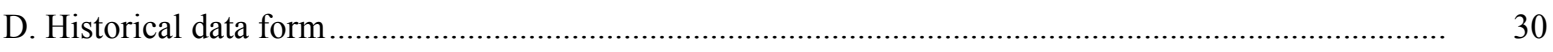

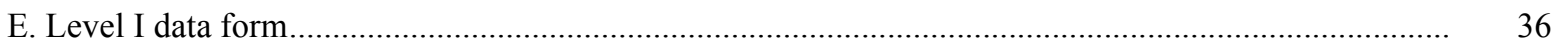

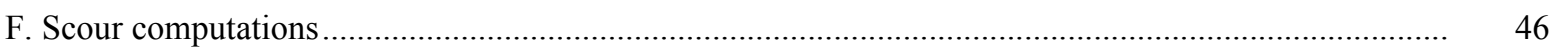

\section{FIGURES}

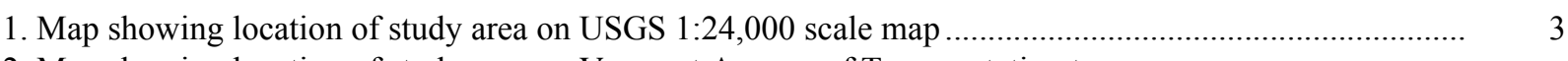

2. Map showing location of study area on Vermont Agency of Transportation town
highway map

3. Structure HUNTTH00220031 viewed from upstream (June 25, 1996) .................................................. 5

4. Downstream channel viewed from structure HUNTTH00220031 (June 25, 1996)............................. 5

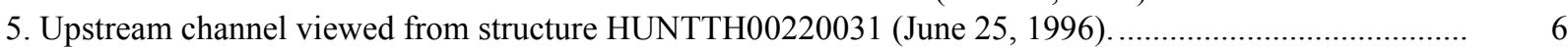

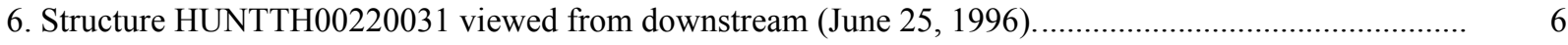

7. Water-surface profiles for the 100- and 500-year discharges at structure

HUNTTH00220031 on Town Highway 22, crossing Brush Brook,

Huntington, Vermont.

8. Scour elevations for the 100- and 500-year discharges at structure

HUNTTH00220031 on Town Highway 22, crossing Brush Brook,

Huntington, Vermont.

\section{TABLES}

1. Remaining footing/pile depth at abutments for the 100-year discharge at structure

HUNTTH00220031 on Town Highway 22, crossing Brush Brook,

Huntington, Vermont....

2. Remaining footing/pile depth at abutments for the 500-year discharge at structure

HUNTTH00220031 on Town Highway 22, crossing Brush Brook,

Huntington, Vermont....

3
4
5
5
6
6




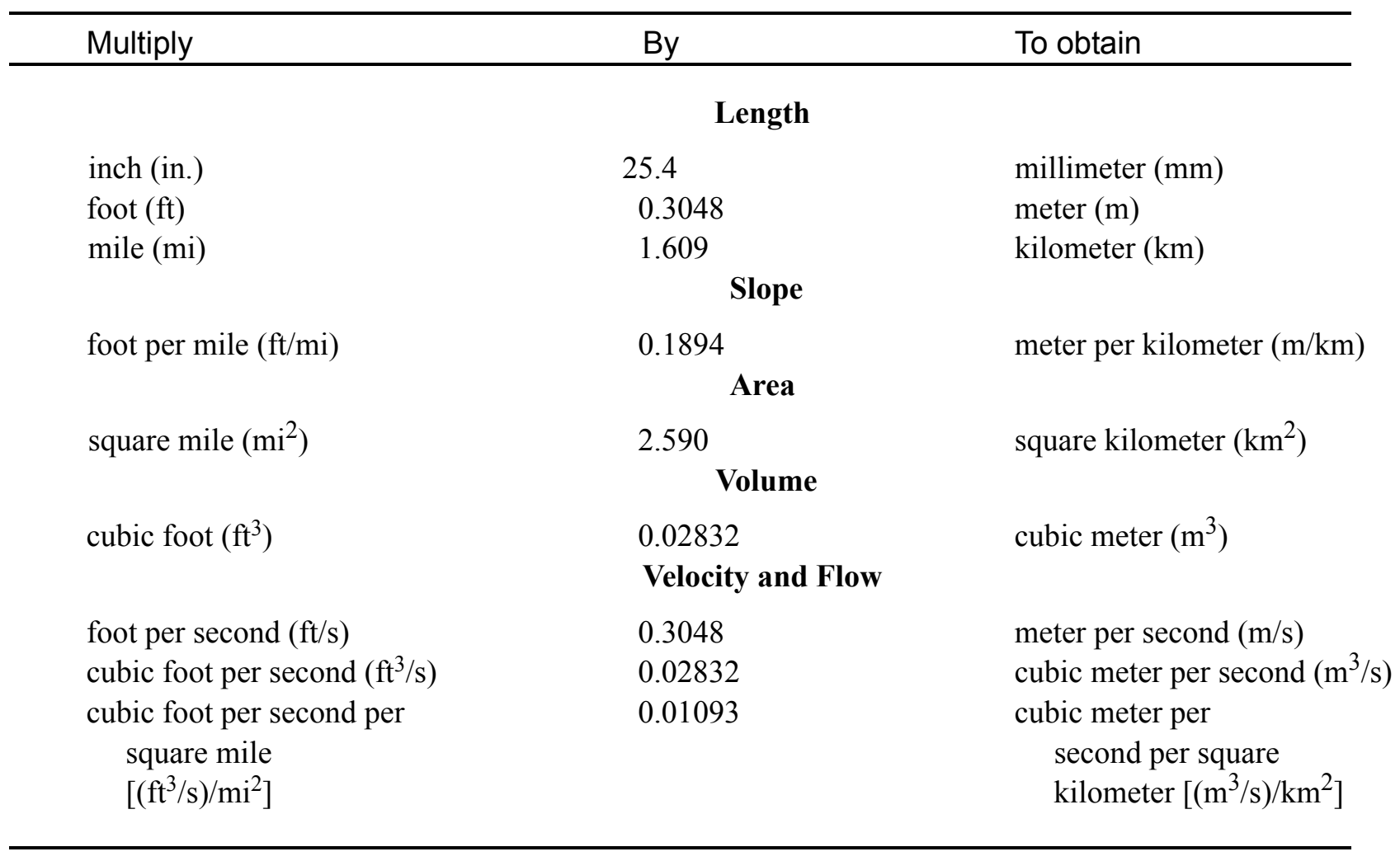

\section{OTHER ABBREVIATIONS}

$\begin{array}{lrlr}\mathrm{BF} & \text { bank full } & \text { LWW } & \text { left wingwall } \\ \mathrm{cfs} & \text { cubic feet per second } & \text { MC } & \text { main channel } \\ \mathrm{D}_{50} & \text { median diameter of bed material } & \text { RAB } & \text { right abutment } \\ \mathrm{DS} & \text { downstream } & \text { RABUT } & \text { face of right abutment } \\ \mathrm{elev} & \text { elevation } & \text { RB } & \text { right bank } \\ \mathrm{f} / \mathrm{p} & \text { flood plain } & \text { ROB } & \text { right overbank } \\ \mathrm{ft}^{2} & \text { square feet } & \text { RWW } & \text { right wingwall } \\ \mathrm{ft} / \mathrm{ft} & \text { feet per foot } & \text { TH } & \text { town highway } \\ \mathrm{JCT} & \text { junction } & \text { UB } & \text { under bridge } \\ \mathrm{LAB} & \text { left abutment } & \text { US } & \text { upstream } \\ \mathrm{LABUT} & \text { face of left abutment } & \text { USGS } & \text { United States Geological Survey } \\ \mathrm{LB} & \text { left bank } & \text { VTAOT Vermont Agency of Transportation } \\ \mathrm{LOB} & \text { left overbank } & \text { WSPRO } & \text { water-surface profile model }\end{array}$

In this report, the words "right" and "left" refer to directions that would be reported by an observer facing downstream. Sea level: In this report, "sea level" refers to the National Geodetic Vertical Datum of 1929-- a geodetic datum derived from a general adjustment of the first-order level nets of the United States and Canada, formerly called Sea Level Datum of 1929.

In the appendices, the above abbreviations may be combined. For example, USLB would represent upstream left bank. 


\title{
LEVEL II SCOUR ANALYSIS FOR BRIDGE 31 (HUNTTH00220031) ON TOWN HIGHWAY 22, CROSSING BRUSH BROOK, HUNTINGTON, VERMONT
}

\author{
By Robert H. Flynn and James R. Degnan
}

\section{INTRODUCTION AND SUMMARY OF RESULTS}

This report provides the results of a detailed Level II analysis of scour potential at structure HUNTTH00220031 on Town Highway 22 crossing Brush Brook, Huntington, Vermont (figures 1-8). A Level II study is a basic engineering analysis of the site, including a quantitative analysis of stream stability and scour (U.S. Department of Transportation, 1993). Results of a Level I scour investigation also are included in Appendix E of this report. A Level I investigation provides a qualitative geomorphic characterization of the study site. Information on the bridge, obtained from Vermont Agency of Transportation (VTAOT) files, was compiled prior to conducting Level I and Level II analyses and is found in Appendix D.

The site is in the Green Mountain section of the New England physiographic province in west-central Vermont. The 5.01- $\mathrm{mi}^{2}$ drainage area is in a predominantly rural and forested basin. In the vicinity of the study site, the surface cover consists of trees and brush.

In the study area, Brush Brook has an incised, straight channel with a slope of approximately $0.06 \mathrm{ft} / \mathrm{ft}$, an average channel top width of $44 \mathrm{ft}$ and an average bank height of $4 \mathrm{ft}$. The channel bed material ranges from boulder to gravel with a median grain size $\left(\mathrm{D}_{50}\right)$ of $107.0 \mathrm{~mm}(0.352 \mathrm{ft})$. The geomorphic assessment at the time of the Level I and Level II site visit on June 25, 1996, indicated that the reach was stable.

The Town Highway 22 crossing of Brush Brook is a 34-ft-long, one-lane bridge consisting of one 30-foot steel I-beam span (Vermont Agency of Transportation, written communication, November 30, 1995). The opening length of the structure parallel to the bridge face is $31.2 \mathrm{ft}$. The bridge is supported by vertical, concrete abutments with wingwalls. The channel is skewed approximately 15 degrees to the opening while the computed opening-skew-to-roadway is 10 degrees. The VTAOT computed opening-skewto-roadway is 2 degrees.

A scour hole $1.0 \mathrm{ft}$ deeper than the mean thalweg depth was observed at the downstream end of the left abutment during the Level I assessment. The only scour protection measure at the site was type- 2 stone fill (less than 36 inches diameter) along the upstream right bank. Additional details describing conditions at the site are included in the Level II Summary and Appendices D and E. 
Scour depths and recommended rock rip-rap sizes were computed using the general guidelines described in Hydraulic Engineering Circular 18 (Richardson and others, 1995) for the 100- and 500-year discharges. In addition, the incipient roadway-overtopping discharge is determined and analyzed as another potential worst-case scour scenario. Total scour at a highway crossing is comprised of three components: 1) long-term streambed degradation; 2) contraction scour (due to accelerated flow caused by a reduction in flow area at a bridge) and; 3 ) local scour (caused by accelerated flow around piers and abutments). Total scour is the sum of the three components. Equations are available to compute depths for contraction and local scour and a summary of the results of these computations follows.

Contraction scour for all modelled flows was computed to be zero ft. Abutment scour ranged from 7.0 to $10.5 \mathrm{ft}$. The worst-case abutment scour occurred at the 500-year discharge for the left abutment and at the incipient-overtopping discharge for the right abutment. Additional information on scour depths and depths to armoring are included in the section titled "Scour Results". Scoured-streambed elevations, based on the calculated scour depths, are presented in tables 1 and 2. A cross-section of the scour computed at the bridge is presented in figure 8 . Scour depths were calculated assuming an infinite depth of erosive material and a homogeneous particle-size distribution.

It is generally accepted that the Froehlich equation (abutment scour) gives "excessively conservative estimates of scour depths" (Richardson and others, 1995, p. 47). Usually, computed scour depths are evaluated in combination with other information including (but not limited to) historical performance during flood events, the geomorphic stability assessment, existing scour protection measures, and the results of the hydraulic analyses. Therefore, scour depths adopted by VTAOT may differ from the computed values documented herein. 


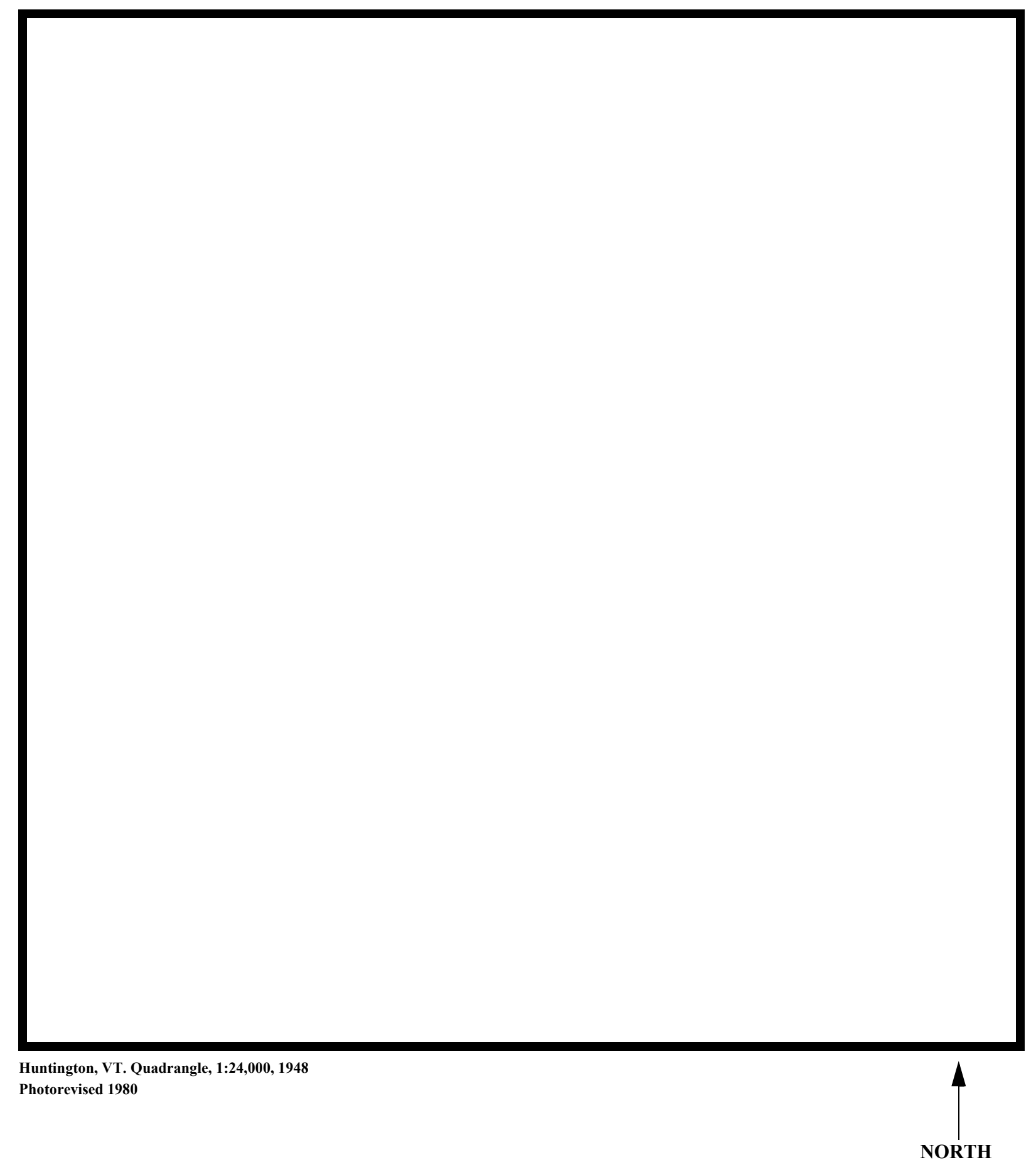

Figure 1. Location of study area on USGS 1:24,000 scale map. 
Figure 2. Location of study area on Vermont Agency of Transportation town highway map. 

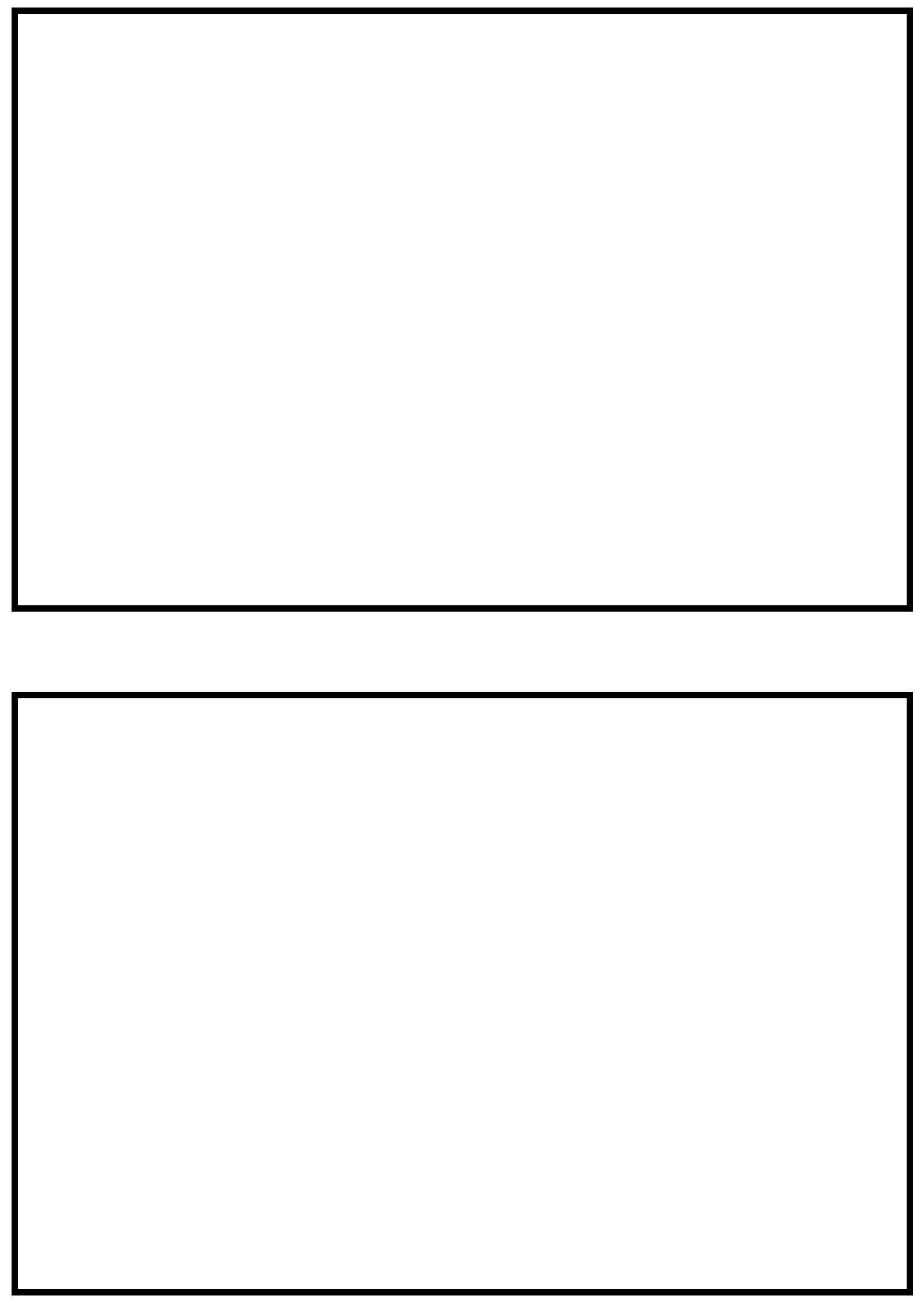

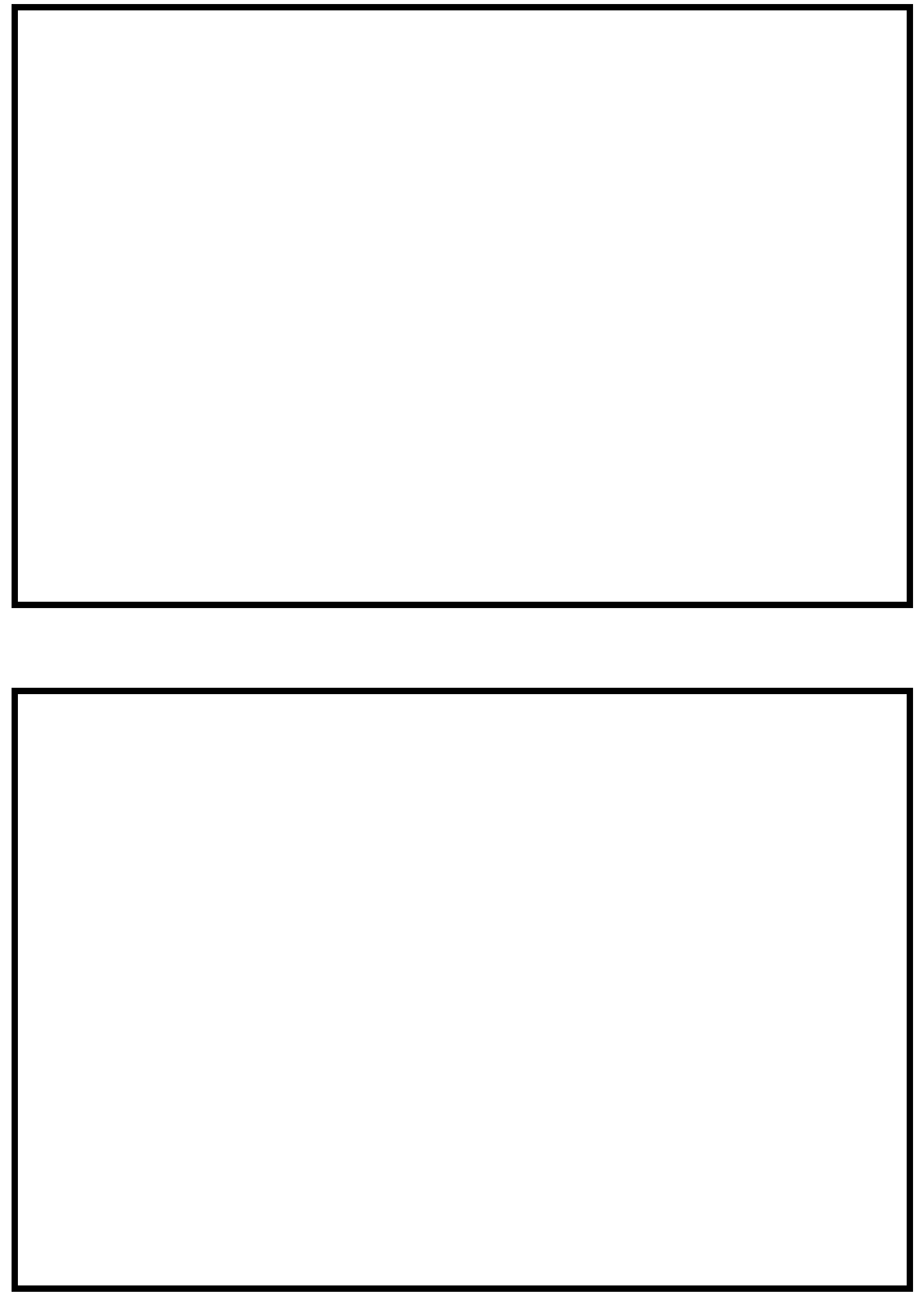


\section{LEVEL II SUMMARY}

\begin{tabular}{llllll} 
Structure Number & HUNTTH00220031 & & \multicolumn{2}{c}{ Brush Brook } \\
Stream & & & \\
County & Chittenden & Road & TH31 & District & 5
\end{tabular}

\section{Description of Bridge}

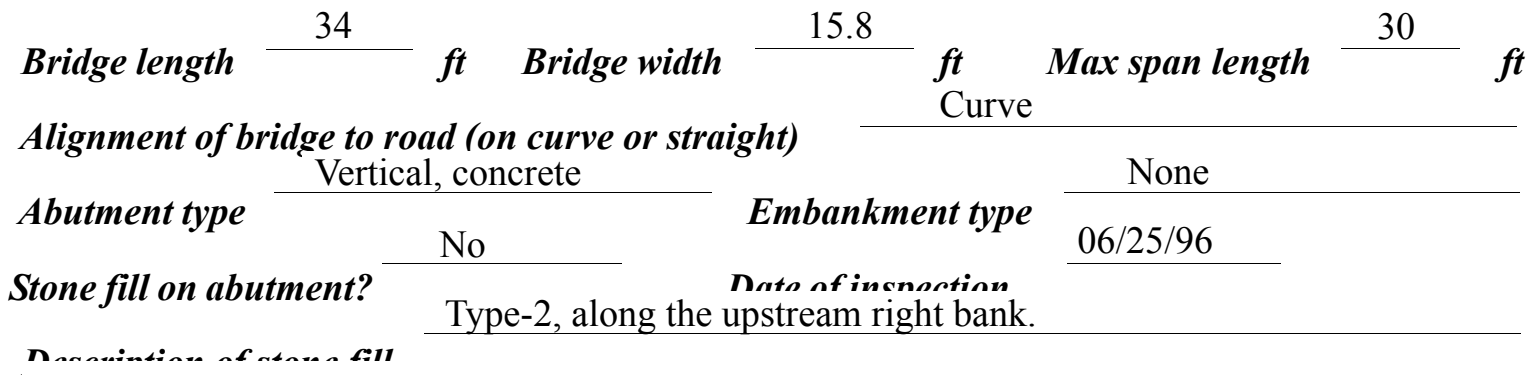

Abutments and wingwalls are concrete. There is a one

foot deep scour hole in front of the downstream end of the left abutment.

Yes

Is bridge skewed to flood flow according to No ' survey?

Angle

Debris accumulation on bridge at time of Level I or Level II site visit:

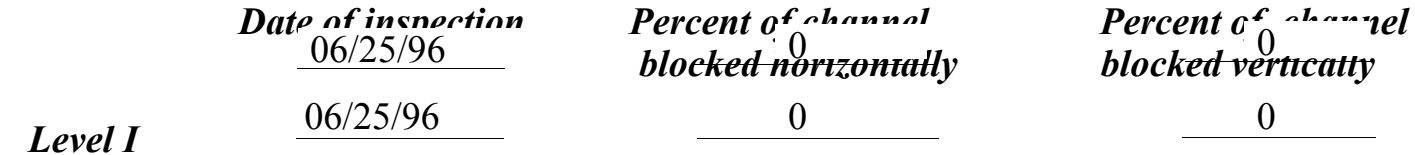

Level II

Moderate. There is debris (logs and branches) in the upstream and downstream channel.

Potential for debris

None noted as of 06/25/96.

Doscriho any, foaturos noar ar at tho hridos that mav, affoct flou, (includo ahsorvation dato) 


\section{Description of the Geomorphic Setting}

General topography The channel is located within a moderate relief valley setting with steep valley walls on both sides.

Geomorphic conditions at bridge site: downstream (DS), upstream (US)

Date of inspection $\quad 06 / 25 / 96$

DS left: $\quad$ Steep channel bank to a narrow overbank.

DS right: $\quad$ Moderately sloped channel bank to a road on the overbank.

US left: $\quad$ Moderately sloped channel bank to a narrow overbank.

US right: $\quad$ Steep channel bank to a road on the overbank.

\section{Description of the Channel}

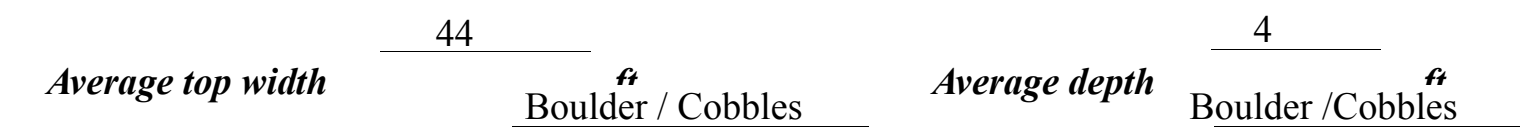

Predominant bed material

Bank material

Straight and stable

with non-alluvial channel boundaries.

$06 / 25 / 96$

Vegetative co ${ }^{1}$ Trees and brush along immediate banks with grass on the overbanks.

DS left: $\quad$ Trees and brush.

DS right: $\quad$ Trees and brush along immediate banks with grass on the overbanks.

US left: $\quad$ Trees and brush.

US right: $\quad$ Yes

Do banks appear stable? -

date of observatton.

The assessment of $06 /$

25/96 noted flow conditions are influenced by boulders on the banks and in the channel. In Describe any obstructions in channel and date of observation.

addition, some debris is caught on boulders in the channel upstream. 


\section{Hydrology}

Drainage area $\stackrel{5.01}{\mathrm{mi}^{2}}$

Percentage of drainage area in physiographic provinces: (approximate)

Physiographic province/section

New England/Green Mountain
Percent of drainage area 100

Is drainage area considered rural or urban? Rural _ Describe any significant urbanization:

Although there are not a significant number of homes, there are a few houses on the upstream and downstream overbank areas.

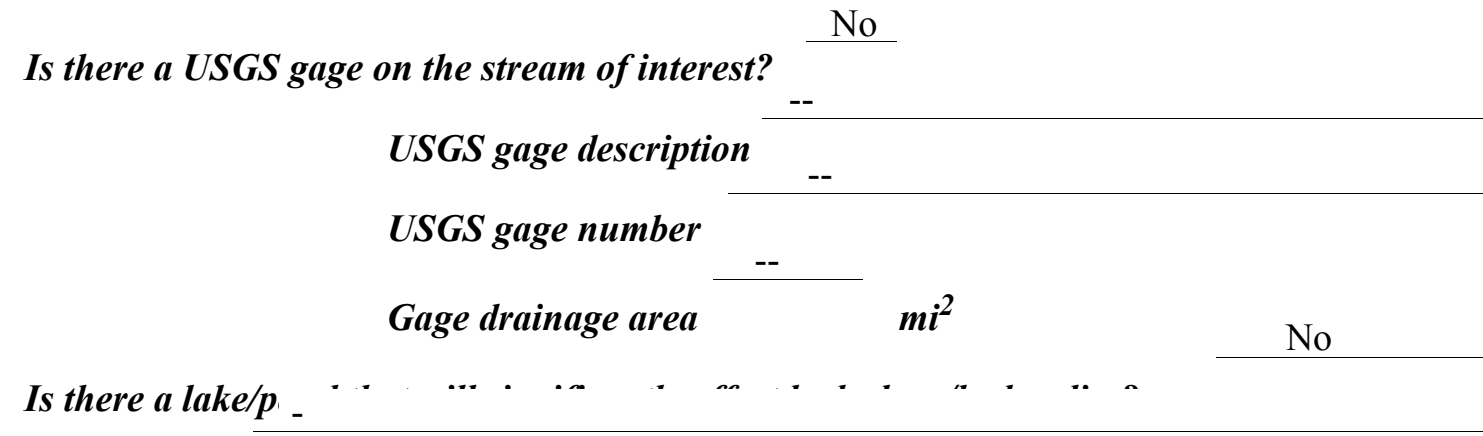

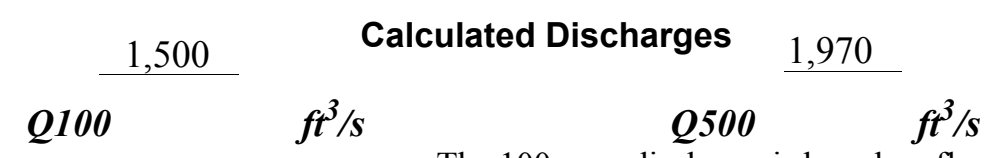

The 100-year discharge is based on flood frequency

estimates available from the VTAOT database. The 500-year discharge is based on a drainage area relationship [(5.0 / 9.2)exp 0.55] with bridge number 12 in Huntington. Bridge number 12 crosses Brush Brook downstream of this site and has flood frequency estimates available from the VTAOT database. The drainage area above bridge number 12 is 9.2 square miles. The values selected are within a range defined by discharge frequency curves which were developed from empirical relationships and extended to the 500-year discharge (Benson, 1962; Johnson and Tasker, 1974; FHWA, 1983; Potter, 1957a\&b;

Talbot, 1887). 


\section{Description of the Water-Surface Profile Model (WSPRO) Analysis}

Datum for WSPRO analysis (USGS survey, sea level, VTAOT plans)

USGS survey

Datum tie between USGS survey and VTAOT plans

None

Description of reference marks used to determine USGS datum. $\quad$ RM1 is a chiseled X on top of the upstream end of the left abutment (elev. $498.15 \mathrm{ft}$, arbitrary survey datum). RM2 is a nail, $6 \mathrm{ft}$ above the ground, in a $1.5 \mathrm{ft}$ diameter maple tree located $30 \mathrm{ft}$ downstream on the right overbank and $10 \mathrm{ft}$ streamward from the road (elev. $500.01 \mathrm{ft}$, arbitrary survey datum).

\section{Cross-Sections Used in WSPRO Analysis}

\begin{tabular}{|c|c|c|c|}
\hline${ }^{1}$ Cross-section & $\begin{array}{c}\text { Section } \\
\text { Reference } \\
\text { Distance } \\
\text { (SRD) in feet }\end{array}$ & $\begin{array}{c}{ }^{2} \text { Cross-section } \\
\text { development }\end{array}$ & Comments \\
\hline EXITX & -28 & 1 & Exit section \\
\hline FULLV & 0 & 2 & $\begin{array}{l}\text { Downstream Full-valley } \\
\text { section (Templated from } \\
\text { EXITX) }\end{array}$ \\
\hline BRIDG & 0 & 1 & Bridge section \\
\hline RDWAY & 10 & 1 & Road Grade section \\
\hline APPRO & 50 & 2 & $\begin{array}{l}\text { Modelled Approach sec- } \\
\text { tion (Templated from } \\
\text { APTEM) }\end{array}$ \\
\hline APTEM & 53 & 1 & $\begin{array}{l}\text { Approach section as sur- } \\
\text { veyed (Used as a tem- } \\
\text { plate) }\end{array}$ \\
\hline
\end{tabular}

${ }^{1}$ For location of cross-sections see plan-view sketch included with Level I field form, Appendix E. For more detail on how cross-sections were developed see WSPRO input file. 


\section{Data and Assumptions Used in WSPRO Model}

Hydraulic analyses of the reach were done by use of the Federal Highway Administration's WSPRO step-backwater computer program (Shearman and others, 1986, and Shearman, 1990). The analyses reported herein reflect conditions existing at the site at the time of the study. Furthermore, in the development of the model it was necessary to assume no accumulation of debris or ice at the site. Results of the hydraulic model are presented in the Bridge Hydraulic Summary, Appendix B, and figure 7.

Channel roughness factors (Manning's " $n$ ") used in the hydraulic model were estimated using field inspections at each cross section following the general guidelines described by Arcement and Schneider (1989). Final adjustments to the values were made during the modelling of the reach. Channel " $n$ " values for the reach ranged from 0.060 to 0.070 , and overbank " $\mathrm{n}$ " values ranged from 0.035 to 0.065 .

Critical depth at the exit section (EXITX) was assumed as the starting water surface for all modelled discharges and was computed based on minimum specific energy. Normal depth was computed by use of the slope-conveyance method outlined in the user's manual for WSPRO (Shearman, 1990). The slope used was $0.0626 \mathrm{ft} / \mathrm{ft}$, which was estimated from the topographic map (U.S. Geological Survey, 1948, photorevised, 1980). This slope resulted in a normal depth up to $0.5 \mathrm{ft}$ less than critical depth and WSPRO defaulted to critical depth. The assumption of critical depth in the downstream reach for all modelled discharges is considered to be a satisfactory solution.

The surveyed approach section (APTEM) was moved along the approach channel slope $(0.068 \mathrm{ft} / \mathrm{ft})$ to establish the modelled approach section (APPRO), one bridge length upstream of the upstream face as recommended by Shearman and others (1986). This location also provides a consistent method for determining scour variables. 


\section{Bridge Hydraulics Summary}

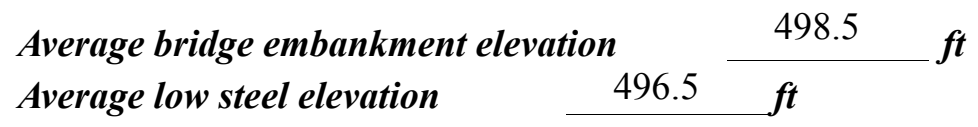

\begin{tabular}{|c|c|c|c|c|}
\hline \multirow{2}{*}{\multicolumn{3}{|c|}{$\begin{array}{l}\text { 100-year discharge } \\
\text { Water-surface elevation in bridge opening }\end{array}$}} & \multirow{2}{*}{\multicolumn{2}{|c|}{$496.6 \mathrm{ft}$}} \\
\hline & & & & \\
\hline Road overtopping? & $\mathrm{N}$ & \multicolumn{3}{|c|}{ Discharge over road } \\
\hline \multicolumn{5}{|c|}{ Area of flow in bridge opening } \\
\hline \multicolumn{3}{|c|}{ Average velocity in bridge opening } & $f t / s$ & \\
\hline \multicolumn{3}{|c|}{ Maximum WSPRO tube velocity at bridge } & 11.6 & $f t / s$ \\
\hline
\end{tabular}

Water-surface elevation at Approach section with bridge Water-surface elevation at Approach section without bridge 498.3 Amount of backwater caused by bridge 2.5 it 495.8

500-year discharge $\quad 1,970 \quad \mathrm{ft}^{3} / \mathrm{s}$

Water-surface elevation in bridge opening $496.5 \mathrm{ft}$

Road overtopping? ___ Y Discharge over road __ $215 \mathrm{ft}^{3} / \mathrm{s}$

Area of flow in bridge opening $\quad 185 \quad \mathrm{ft}^{2}$

Average velocity in bridge opening $\quad 9.5 \mathrm{ft} / \mathrm{s}$

Maximum WSPRO tube velocity at bridge 13.1 , s

Water-surface elevation at Approach section with bridge

Water-surface elevation at Approach section without bridge

Amount of backwater caused by bridge $\quad 2.6$, $t$

499.3

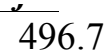

Incipient overtopping discharge $\quad 1,610 \mathrm{ft}^{3} / \mathrm{s}$

Water-surface elevation in bridge opening $496.8 \quad t$

Area of flow in bridge opening

Average velocity in bridge opening

$188 \mathrm{ft}^{2}$

Maximum WSPRO tube velocity at bridge

$8.6 \mathrm{ft} / \mathrm{s}$

$\mathrm{fe}^{\mathrm{ft} / \mathrm{s}} \mathrm{ft} / \mathrm{s}$

Water-surface elevation at Approach section with bridge

Water-surface elevation at Approach section without bridge

498.6 Amount of backwater caused by bridge

$2.5 . i$




\section{Scour Analysis Summary}

\section{Special Conditions or Assumptions Made in Scour Analysis}

Scour depths were computed using the general guidelines described in Hydraulic Engineering Circular 18 (Richardson and others, 1995). Scour depths were calculated assuming an infinite depth of erosive material and a homogeneous particle-size distribution. The results of the scour analysis are presented in tables 1 and 2 and a graph of the scour depths is presented in figure 8 .

At this site, the 100-year, 500-year, and incipient roadway-overtopping discharges resulted in unsubmerged orifice flow. Contraction scour at bridges with orifice flow is best estimated by use of the Chang pressure-flow scour equation (oral communication, J. Sterling Jones, October 4, 1996). Thus, contraction scour for these discharges was computed by use of the Chang equation (Richardson and others, 1995, p. 145-146).

For comparison, contraction scour for the discharges resulting in orifice flow was computed by use of the Laursen clear-water contraction scour equation (Richardson and others, 1995, p. 32, equation 20) and the Umbrell pressure-flow equation (Richardson and others, 1995, p. 144) and presented in Appendix F. Furthermore, for those discharges resulting in unsubmerged orifice flow, contraction scour was computed by substituting estimates for the depth of flow at the downstream bridge face in the contraction scour equations. Results with respect to these substitutions are provided in Appendix F.

Abutment scour was computed by use of the Froehlich equation (Richardson and others, 1995, p. 48, equation 28). Variables for the Froehlich equation include the Froude number of the flow approaching the embankments, the length of the embankment blocking flow, and the depth of flow approaching the embankment less any roadway overtopping. 


\section{Scour Results}

$$
\text { 100-yr discharge 500-yrdischarge }
$$

(Scour depths in feet)

Main channel

Live-bed scour

Clear-water scour

Depth to armoring

Left overbank

Right overbank

Local scour:

Abutment scour

Left abutment

Right abutment

Pier scour

Pier 1

Pier 2

Pier 3
7.8

7.9-
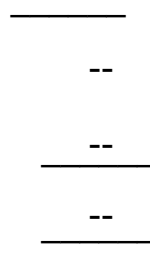

10.5

$7.0-$
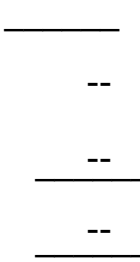

$\sqrt{2+2}$
Incipient
chtopping
charge 


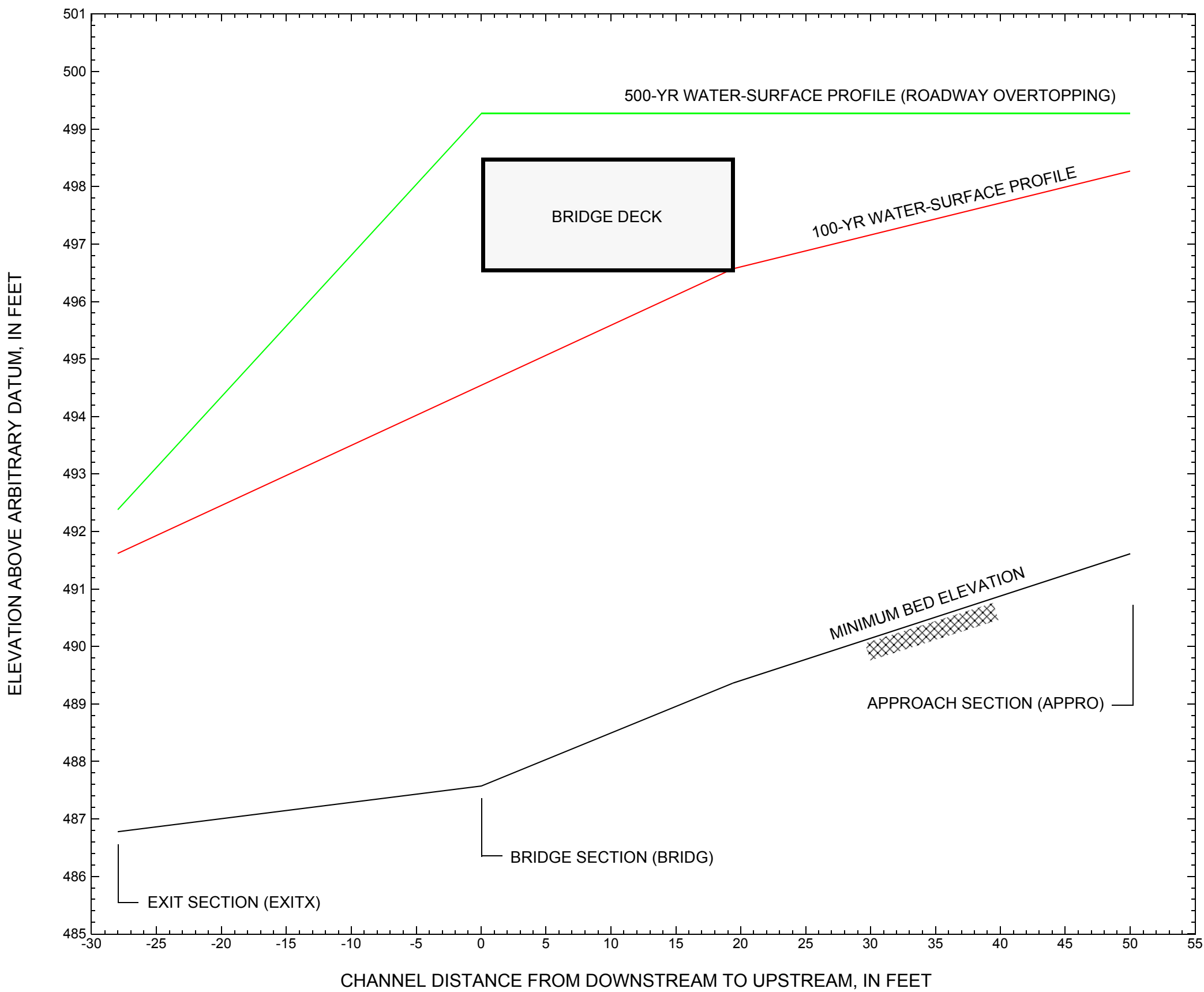

Figure 7. Water-surface profiles for the 100- and 500-yr discharges at structure HUNTTH00220031 on Town Highway 22, crossing Brush Brook, Huntington, Vermont. 


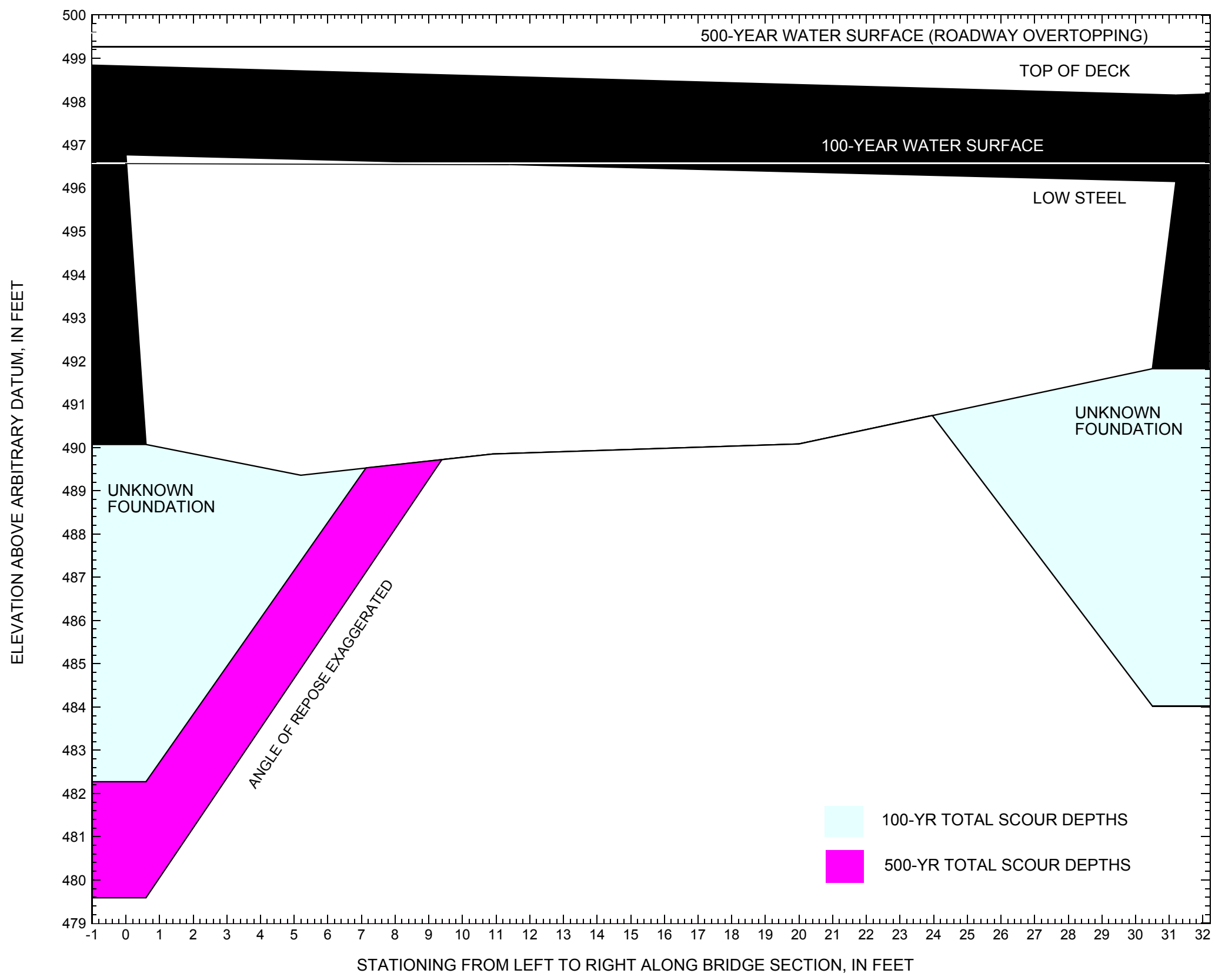

Figure 8. Scour elevations for the 100-yr and 500-yr discharges at structure HUNTTH00220031 on Town Highway 22, crossing Brush Brook, Huntington, Vermont. 
Table 1. Remaining footing/pile depth at abutments for the 100-year discharge at structure HUNTTH00220031 on Town Highway 22, crossing Brush Brook, Huntington, Vermont.

[VTAOT, Vermont Agency of Transportation; --,no data]

\begin{tabular}{|c|c|c|c|c|c|c|c|c|c|c|c|}
\hline Description & Station ${ }^{1}$ & $\begin{array}{l}\text { VTAOT } \\
\text { minimum } \\
\text { low-chord } \\
\text { elevation } \\
\text { (feet) }\end{array}$ & $\begin{array}{l}\text { Surveyed } \\
\text { minimum } \\
\text { low-chord } \\
\text { elevation }{ }^{2} \\
\text { (feet) }\end{array}$ & $\begin{array}{c}\text { Bottom of } \\
\text { footing/pile } \\
\text { elevation }{ }^{2} \\
\text { (feet) }\end{array}$ & $\begin{array}{c}\text { Channel } \\
\text { elevation at } \\
\text { abutment/ } \\
\text { pier }^{2} \\
\text { (feet) }\end{array}$ & $\begin{array}{l}\text { Contraction } \\
\text { scour depth } \\
\text { (feet) }\end{array}$ & $\begin{array}{l}\text { Abutment } \\
\text { scour } \\
\text { depth } \\
\text { (feet) }\end{array}$ & $\begin{array}{l}\text { Pier } \\
\text { scour } \\
\text { depth } \\
\text { (feet) }\end{array}$ & $\begin{array}{l}\text { Depth of } \\
\text { total scour } \\
\text { (feet) }\end{array}$ & $\begin{array}{c}\text { Elevation of } \\
\text { scour }^{2} \\
\text { (feet) }\end{array}$ & $\begin{array}{c}\text { Remaining } \\
\text { footing/pile } \\
\text { depth } \\
\text { (feet) }\end{array}$ \\
\hline \multicolumn{12}{|c|}{100 -yr. discharge is 1,500 cubic-feet per second } \\
\hline Left abutment & 0.0 & -- & 496.8 & -- & 490.1 & 0.0 & 7.8 & -- & 7.8 & 482.3 & -- \\
\hline Right abutment & 31.2 & -- & 496.2 & -- & 491.8 & 0.0 & 7.9 & -- & 7.9 & 483.9 & -- \\
\hline
\end{tabular}

1.Measured along the face of the most constricting side of the bridge.

2.Arbitrary datum for this study.

Table 2. Remaining footing/pile depth at abutments for the 500-year discharge at structure HUNTTH00220031 on Town Highway 22, crossing Brush Brook, Huntington, Vermont.

[VTAOT, Vermont Agency of Transportation; --, no data]

\begin{tabular}{|c|c|c|c|c|c|c|c|c|c|c|c|}
\hline Description & Station $^{1}$ & $\begin{array}{l}\text { VTAOT } \\
\text { minimum } \\
\text { low-chord } \\
\text { elevation } \\
\text { (feet) }\end{array}$ & $\begin{array}{c}\text { Surveyed } \\
\text { minimum } \\
\text { low-chord } \\
\text { elevation } \\
\text { (feet) }\end{array}$ & $\begin{array}{c}\text { Bottom of } \\
\text { footing/pile } \\
\text { elevation } \\
\text { (feet) }\end{array}$ & $\begin{array}{c}\text { Channel } \\
\text { elevation at } \\
\text { abutment/ } \\
\text { pier }^{2} \\
\text { (feet) }\end{array}$ & $\begin{array}{l}\text { Contraction } \\
\text { scour depth } \\
\text { (feet) }\end{array}$ & $\begin{array}{c}\text { Abutment } \\
\text { scour } \\
\text { depth } \\
\text { (feet) }\end{array}$ & $\begin{array}{l}\text { Pier } \\
\text { scour } \\
\text { depth } \\
\text { (feet) }\end{array}$ & $\begin{array}{l}\text { Depth of } \\
\text { total scour } \\
\text { (feet) }\end{array}$ & $\begin{array}{c}\text { Elevation of } \\
\text { scour }^{2} \\
\text { (feet) }\end{array}$ & $\begin{array}{c}\text { Remaining } \\
\text { footing/pile } \\
\text { depth } \\
\text { (feet) }\end{array}$ \\
\hline \multicolumn{12}{|c|}{ 500-yr. discharge is 1,970 cubic-feet per second } \\
\hline Left abutment & 0.0 & -- & 496.8 & -- & 490.1 & 0.0 & 10.5 & -- & 10.5 & 479.6 & -- \\
\hline Right abutment & 31.2 & -- & 496.2 & -- & 491.8 & 0.0 & 7.0 & -- & 7.0 & 484.8 & -- \\
\hline
\end{tabular}

1.Measured along the face of the most constricting side of the bridge.

2.Arbitrary datum for this study. 


\section{SELECTED REFERENCES}

Arcement, G.J., Jr., and Schneider, V.R., 1989, Guide for selecting Manning's roughness coefficients for natural channels and flood plains: U.S. Geological Survey Water-Supply Paper 2339, 38 p.

Barnes, H.H., Jr., 1967, Roughness characteristics of natural channels: U.S. Geological Survey Water-Supply Paper 1849,213 p.

Benson, M. A., 1962, Factors Influencing the Occurrence of Floods in a Humid Region of Diverse Terrain: U.S. Geological Survey WaterSupply Paper 1580-B, 64 p.

Brown, S.A. and Clyde, E.S., 1989, Design of riprap revetment: Federal Highway Administration Hydraulic Engineering Circular No. 11, Publication FHWA-IP-89-016, 156 p.

Federal Highway Administration, 1983, Runoff estimates for small watersheds and development of sound design: Federal Highway Administration Report FHWA-RD-77-158.

Federal Highway Administration, 1993, Stream Stability and Scour at Highway Bridges: Participant Workbook: Federal Highway Administration Report FHWA-HI-91-011.

Froehlich, D.C., 1989, Local scour at bridge abutments in Ports, M.A., ed., Hydraulic Engineering--Proceedings of the 1989 National Conference on Hydraulic Engineering: New York, American Society of Civil Engineers, p. 13-18.

Hayes, D.C.,1993, Site selection and collection of bridge-scour data in Delaware, Maryland, and Virginia: U.S. Geological Survey WaterResources Investigation Report 93-4017, 23 p.

Interagency Advisory Committee on Water Data, 1982, Guidelines for determining flood flow frequency: U.S. Geological Survey, Bulletin 17B of the Hydrology Subcommittee, 190 p.

Johnson, C.G. and Tasker, G.D.,1974, Progress report on flood magnitude and frequency of Vermont streams: U.S. Geological Survey OpenFile Report 74-130, 37 p.

Lagasse, P.F., Schall, J.D., Johnson, F., Richardson, E.V., Chang, F., 1995, Stream Stability at Highway Structures: Federal Highway Administration Hydraulic Engineering Circular No. 20, Publication FHWA-IP-90-014, 144 p.

Laursen, E.M., 1960, Scour at bridge crossings: Journal of the Hydraulics Division, American Society of Civil Engineers, v. 86, no. HY2, p. 39-53.

Potter, W. D., 1957a, Peak rates of runoff in the Adirondack, White Mountains, and Maine woods area, Bureau of Public Roads

Potter, W. D., 1957b, Peak rates of runoff in the New England Hill and Lowland area, Bureau of Public Roads

Richardson, E.V. and Davis, S.R., 1995, Evaluating scour at bridges: Federal Highway Administration Hydraulic Engineering Circular No. 18, Publication FHWA-IP-90-017, 204 p.

Richardson, E.V., Simons, D.B., and Julien, P.Y., 1990, Highways in the river environment: Federal Highway Administration Publication FHWA-HI-90-016.

Ritter, D.F., 1984, Process Geomorphology: W.C. Brown Co., Debuque, Iowa, 603 p.

Shearman, J.O., 1990, User's manual for WSPRO--a computer model for water surface profile computations: Federal Highway Administration Publication FHWA-IP-89-027, 187 p.

Shearman, J.O., Kirby, W.H., Schneider, V.R., and Flippo, H.N., 1986, Bridge waterways analysis model; research report: Federal Highway Administration Publication FHWA-RD-86-108, 112 p.

Talbot, A.N., 1887, The determination of water-way for bridges and culverts.

U. S. Department of Housing and Urban Development, Federal Insurance Administration, 1978, Flood Insurance Study, Town of Huntington, Chittenden County, Vermont: Washington, D.C., January 1978.

U.S. Department of Transportation, 1993, Stream stability and scour at highway bridges, Participant Workbook: Federal Highway Administration Publication FHWA HI-91-011.

U.S. Geological Survey, 1980, Huntington, Vermont 7.5 Minute Series quadrangle map: U.S. Geological Survey Topographic Maps, Photorevised 1980, Scale 1:24,000. 


\section{APPENDIX A: \\ WSPRO INPUT FILE}




\section{WSPRO INPUT FILE}

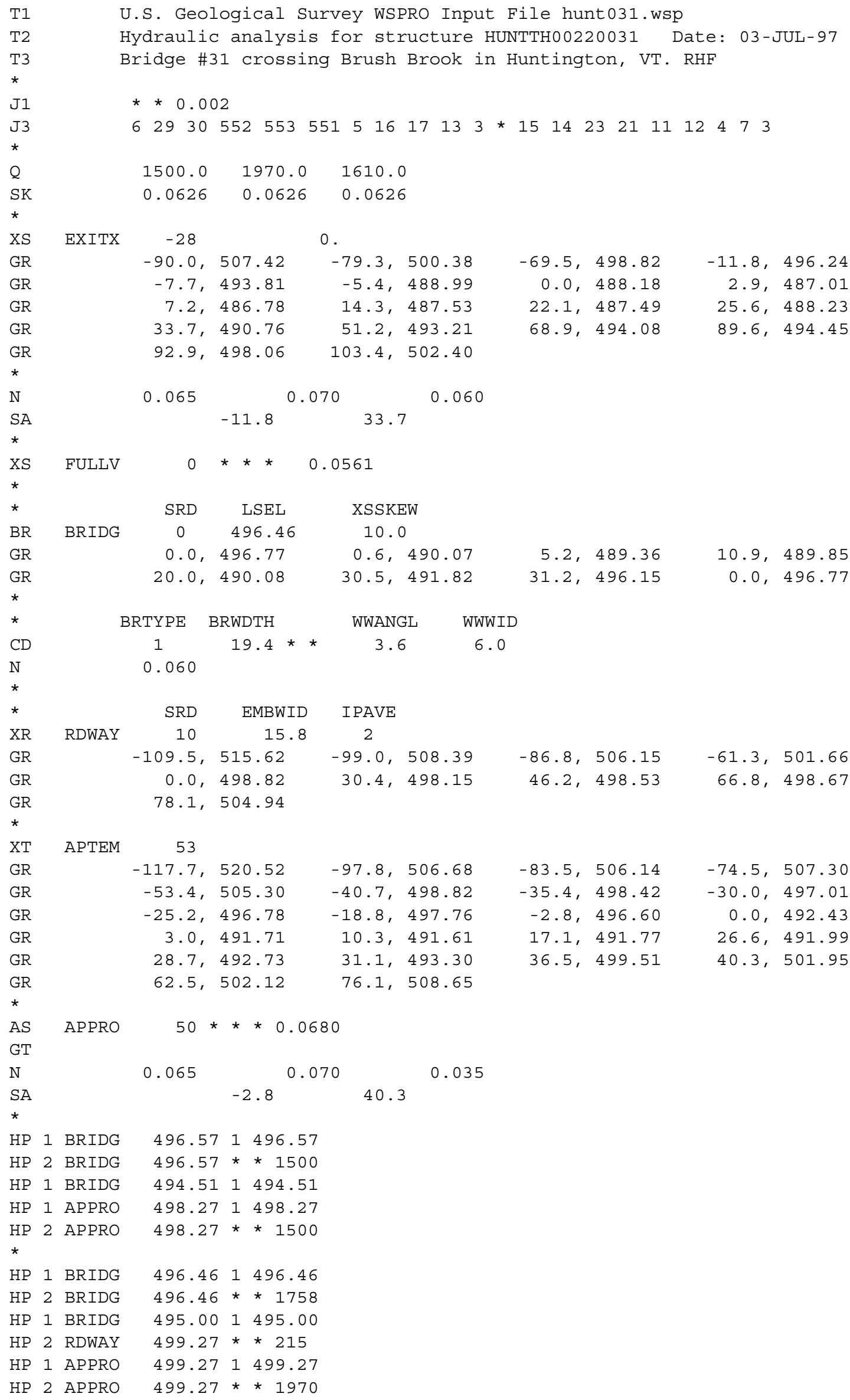




\section{APPENDIX B: \\ WSPRO OUTPUT FILE}


WSPRO OUTPUT FILE

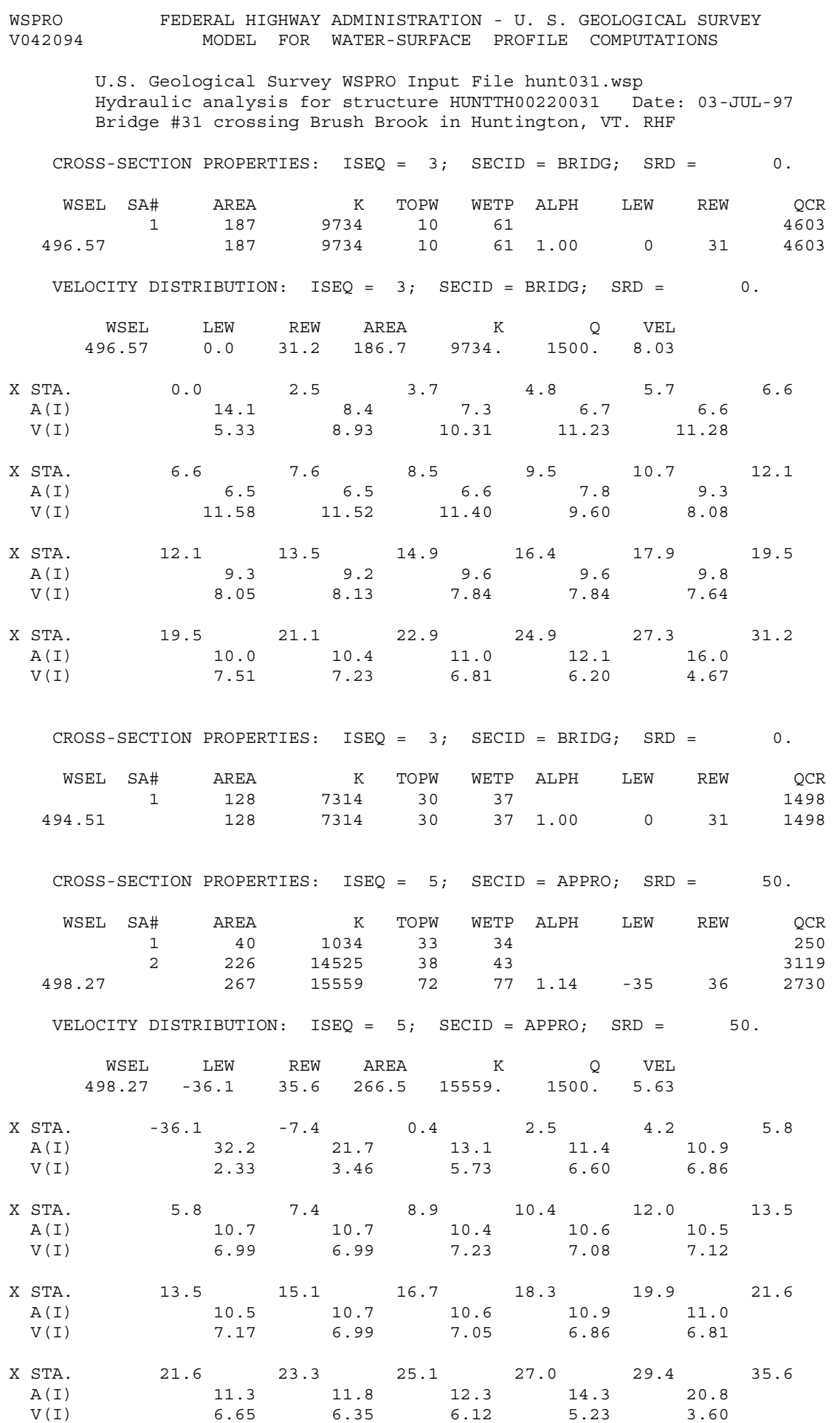




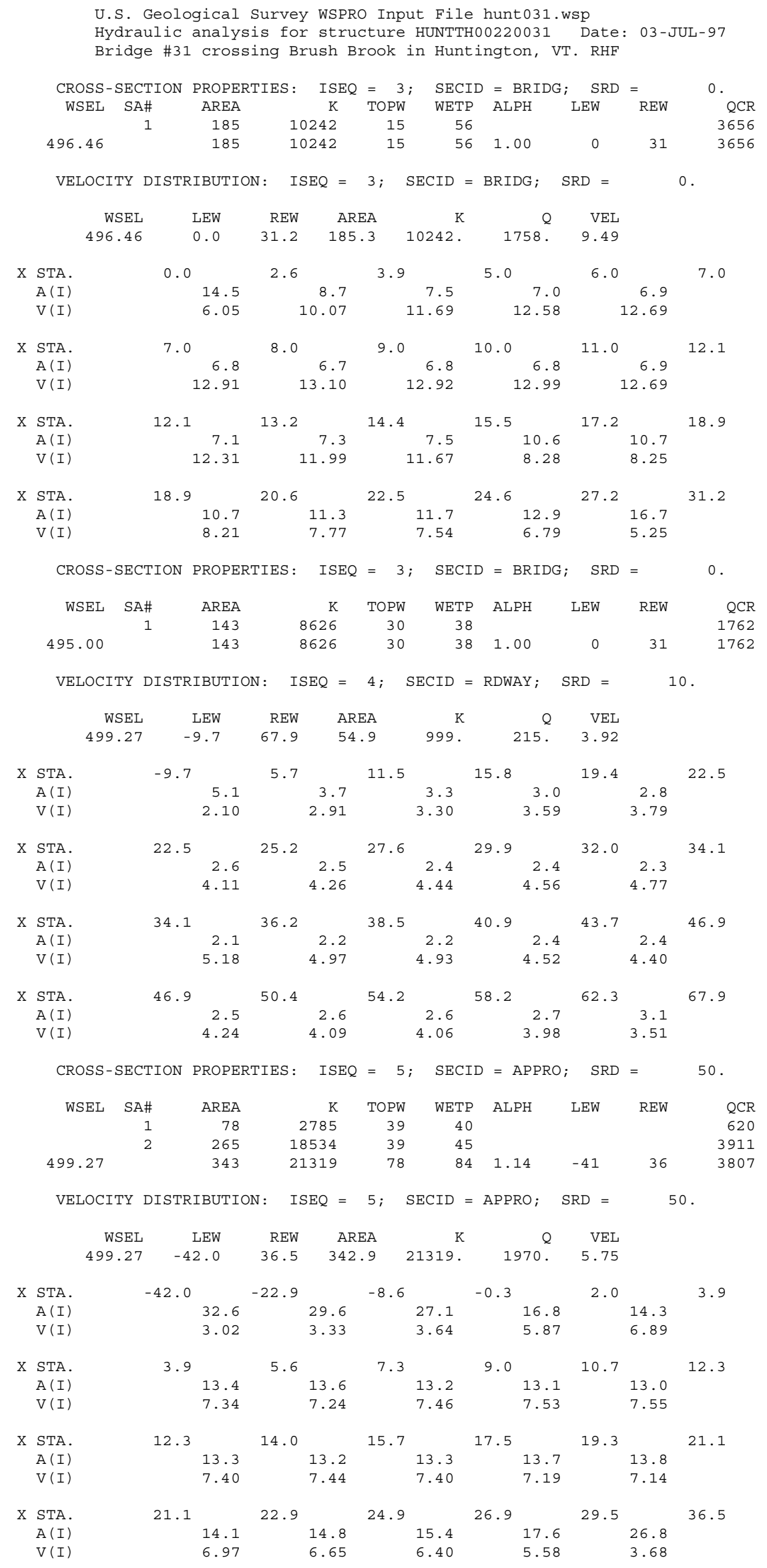


WSPRO OUTPUT FILE (continued)

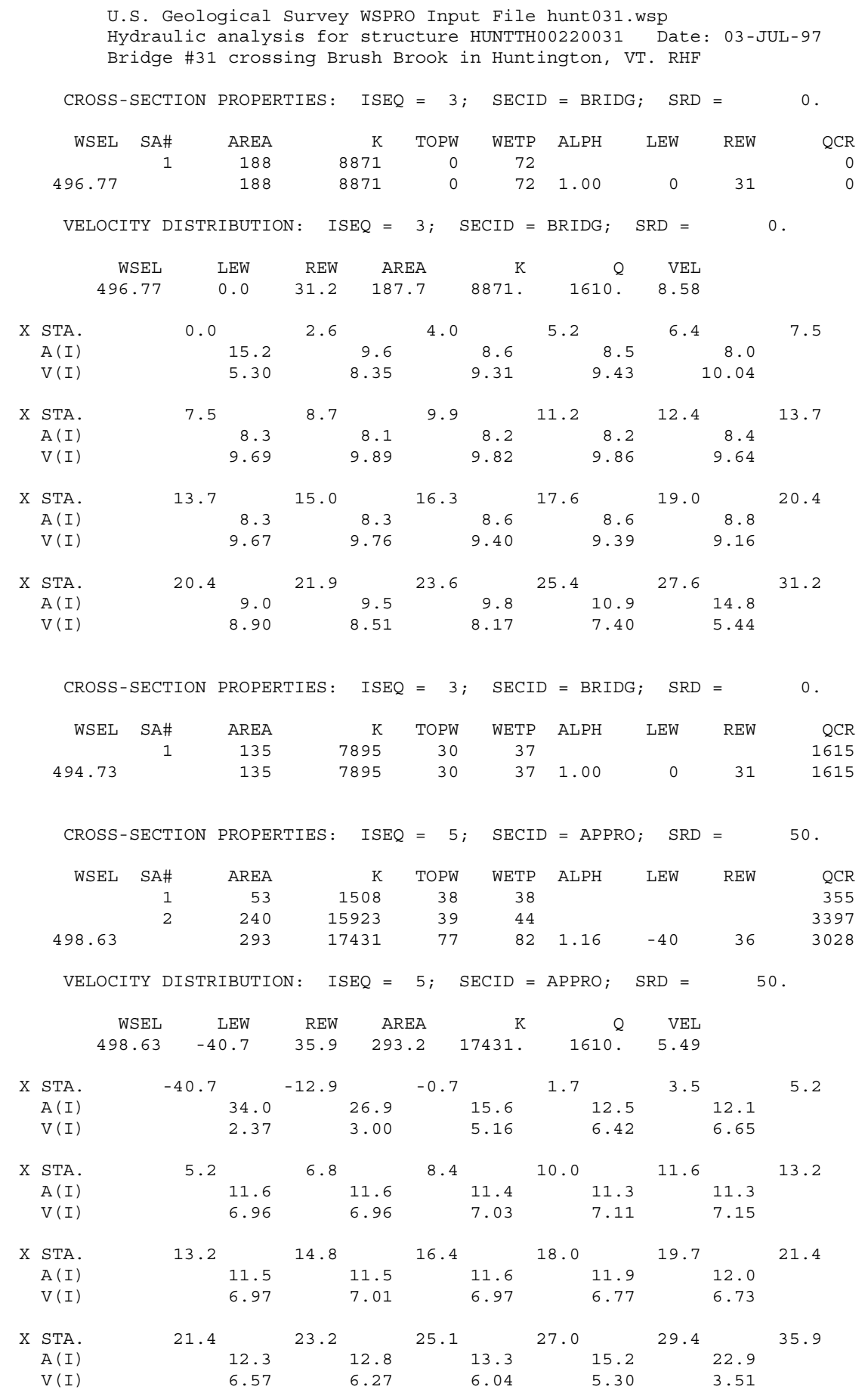


WSPRO OUTPUT FILE (continued)

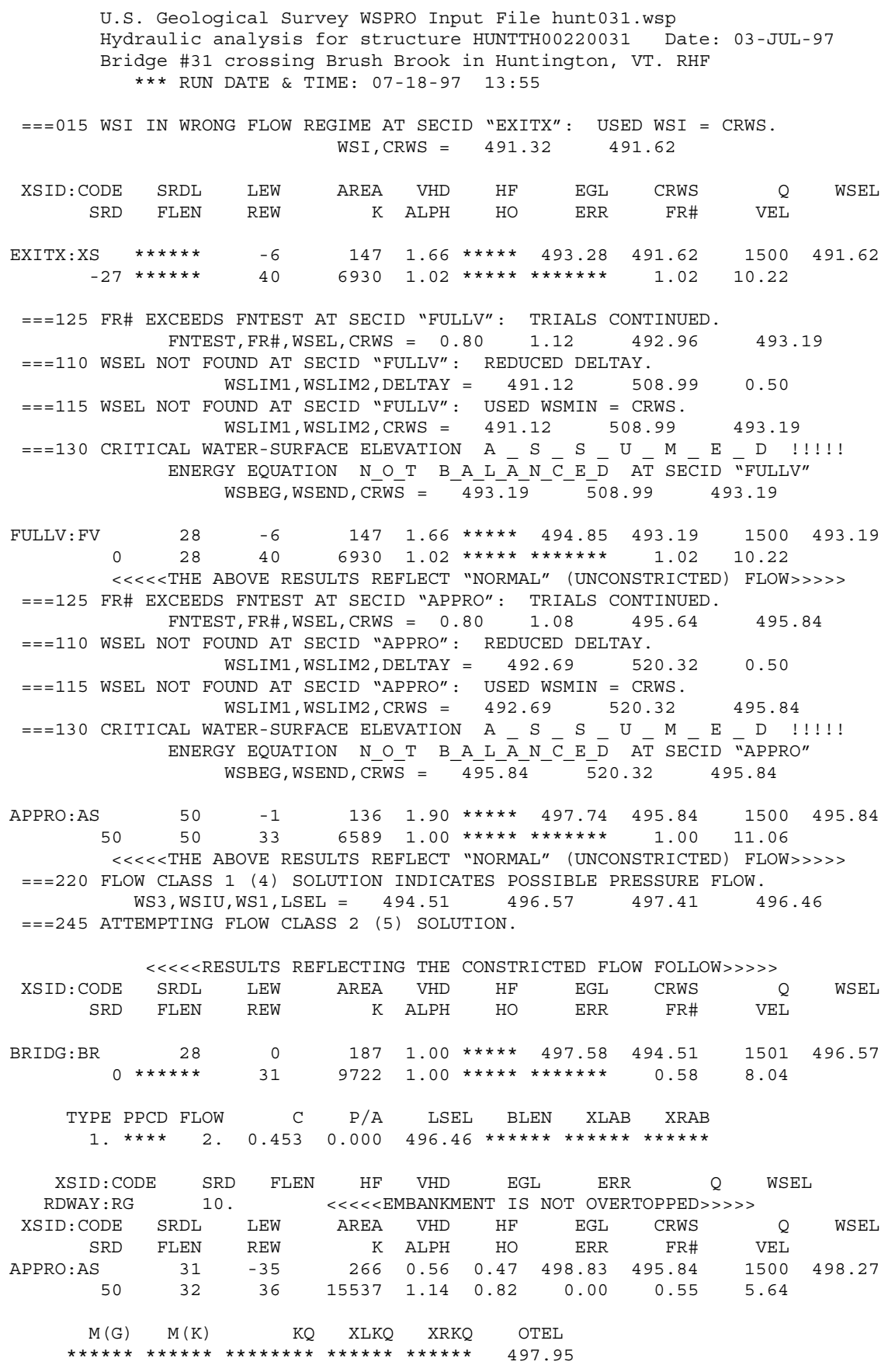

$<<<<$ END OF BRIDGE COMPUTATIONS $>>>>>$

FIRST USER DEFINED TABLE.

$\begin{array}{lrrrrrrrr}\text { XSID : CODE } & \text { SRD } & \text { LEW } & \text { REW } & Q & \text { K } & \text { AREA } & \text { VEL } & \text { WSEL } \\ \text { EXITX : XS } & -28 . & -7 . & 40 . & 1500 . & 6930 . & 147 . & 10.22 & 491.62 \\ \text { FULLV : FV } & 0 . & -7 . & 40 . & 1500 . & 6930 . & 147 . & 10.22 & 493.19 \\ \text { BRIDG : BR } & 0 . & 0 . & 31 . & 1501 . & 9722 . & 187 . & 8.04 & 496.57 \\ \text { RDWAY : RG } & 10 . * * * * * * * * * * * & 0 . & 0 . & 0 . & 2.00 * * * * * * \\ \text { APPRO : AS } & 50 . & -36 . & 36 . & 1500 . & 15537 . & 266 . & 5.64 & 498.27\end{array}$

XSID : CODE XLKQ XRKQ KQ

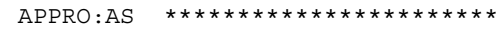

SECOND USER DEFINED TABLE.

XSID:CODE CRWS FR\# YMIN YMAX HF HO VHD EGL WSEL

$\begin{array}{lllllllll}\text { EXITX:XS } & 491.62 & 1.02 & 486.78 & 507.42 * * * * * * * * * * * * & 1.66 & 493.28 & 491.62\end{array}$

$\begin{array}{lllllllll}\text { FULLV : FV } & 493.19 & 1.02 & 488.35 & 508.99 * * * * * * * * * * * * & 1.66 & 494.85 & 493.19\end{array}$

$\begin{array}{llllllll}\text { BRIDG:BR } & 494.51 & 0.58 & 489.36 & 496.77 * * * * * * * * * * * * & 1.00 & 497.58 & 496.57\end{array}$

RDWAY:RG $\quad * * * * * * * * * * * * * * * * \quad 498.15 \quad 515.62 * * * * * * * * * * * * \quad 0.56 \quad 498.51 * * * * * * * *$

$\begin{array}{llllllllll}\text { APPRO:AS } & 495.84 & 0.55 & 491.41 & 520.32 & 0.47 & 0.82 & 0.56 & 498.83 & 498.27\end{array}$ 
WSPRO OUTPUT FILE (continued)

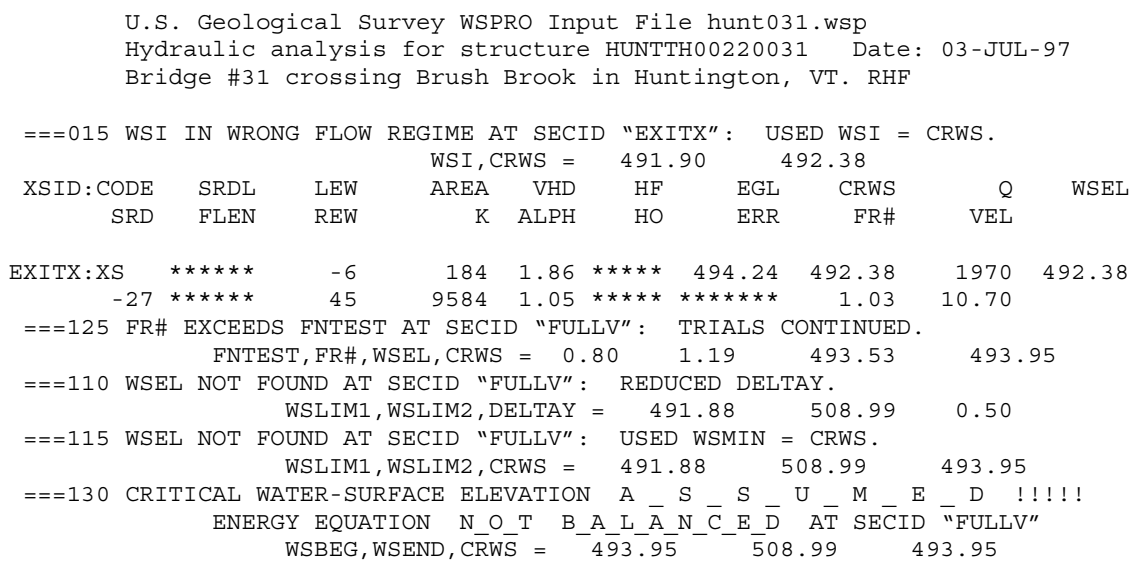


WSPRO OUTPUT FILE (continued)

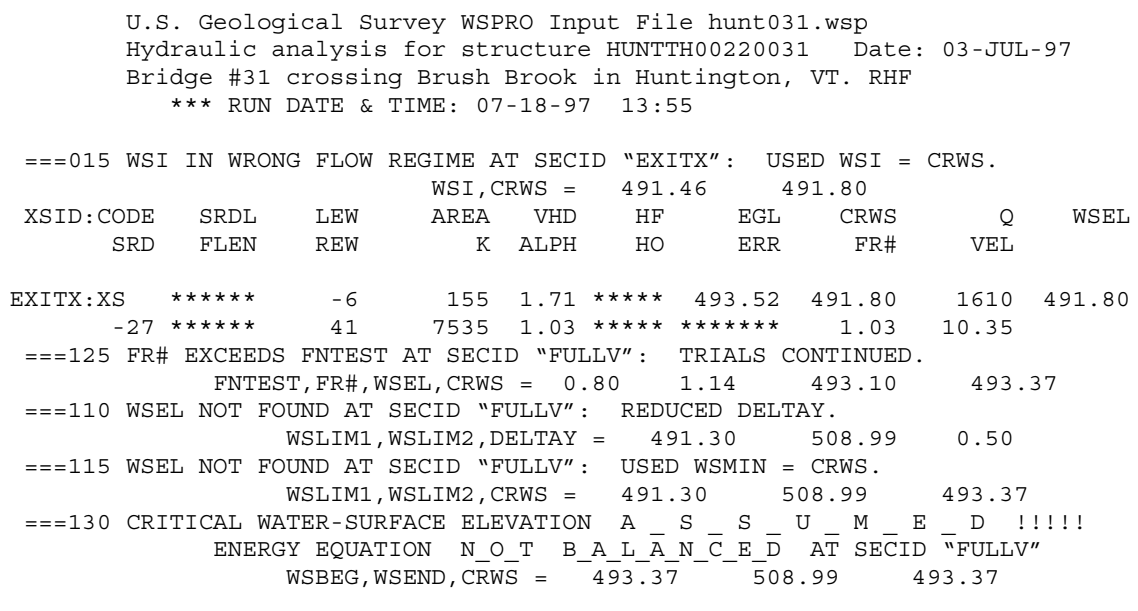




\section{APPENDIX C:}

\section{BED-MATERIAL PARTICLE-SIZE DISTRIBUTION}




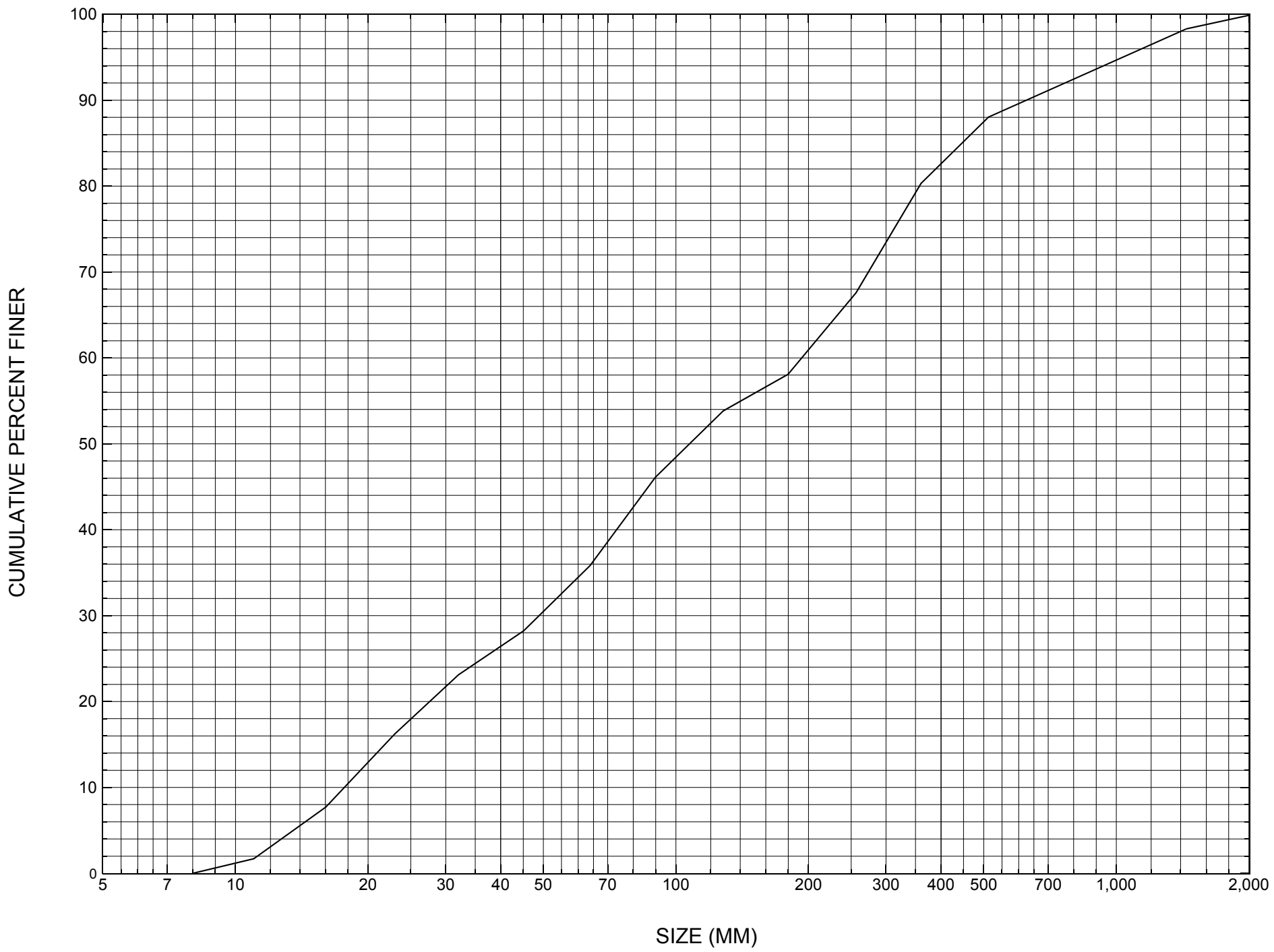

Appendix C. Bed material particle-size distribution for a pebble count in the channel approach of structure HUNTTH00220031, in Huntington, Vermont. 


\section{APPENDIX D: \\ HISTORICAL DATA FORM}




\section{Structure Number HUNTTH00220031}

\section{General Location Descriptive}

Data collected by (First Initial, Full last name) $\underline{\mathbf{L}}$. Medalie

Date $(M M / D D / Y Y) \_\mathbf{1 1} / \underline{30} / \underline{95}$

Highway District Number (I - 2; nn) $\mathbf{0 5}$

Town (FIPS place code; I - 4; nnnnn) $\mathbf{3 4 6 0 0}$

Waterway (I - 6) Brush Brook

Route Number C3022

Topographic Map Huntington

Latitude (I - 16; nnnn.n) $\mathbf{4 4 1 7 8}$
County (FIPS county code; I - 3; nnn)

Mile marker (I - 11; nnn.nnn) $\mathbf{0 0 0 0 0 0}$

Road Name (I - 7): -

Vicinity (I - 9) 1.0 MI TO JCT W CL3 TH21

Hydrologic Unit Code: $\mathbf{0 2 0 1 0 0 0 3}$

Longitude (i - 17; nnnnn.n) $\mathbf{7 2 5 6 0}$

\section{Select Federal Inventory Codes}

FHWA Structure Number (I - 8) $\mathbf{1 0 0 4 0 8 0 0 3 1 0 4 0 8}$

Maintenance responsibility $(I-21 ; n n) \quad \mathbf{0 3}$

Year built (I - 27; YYYY) 1925

Average daily traffic, ADT (I - 29; nnnnnn) $\underline{\mathbf{0 0 0 0 2 0}}$

Year of ADT (I - 30; YY) $\mathbf{9 3}$

Opening skew to Roadway $(I-34 ; n n)$

Operational status $(I-41 ; X) \quad \mathbf{A}$

Structure type (I - 43; nnn) $\mathbf{3 0 2}$

Approach span structure type $(I-44 ; n n n) \quad \mathbf{0 0 0}$

Number of spans (I - 45; nnn) $\underline{\mathbf{0 0 1}}$

Number of approach spans (I - 46; nnnn) $\mathbf{0 0 0 0}$

Comments:

According to the structural inspection report dated 7/17/95, the structure is a steel I-beam type bridge with a wooden deck. The abutments, backwalls, and wingwalls are concrete with a few fine cracks and small leaks overall, including a diagonal spall under the right fascia beam on the RABUT. The LABUT is undermined most of its length. The undermining is up to 15" by 2-3" deep. A diagonal settlement crack under the left fascia beam is 1/4" at the top and fine at the bottom, with some deep spalling along the crack line. The left end and left wingwall have cracks and leaks, with areas of delamination overall. The backwall has several cracks with small leaks and some chipping along the crack lines. A diagonal settlement crack at (Continued, page 33) 


\section{Bridge Hydrologic Data}

Is there hydrologic data available? $\underline{\mathbf{Y}}$ if No, type ctrl-n $h \quad$ VTAOT Drainage area $\left(m i^{2}\right): \underline{\mathbf{5}}$

Terrain character: Hilly to mountainous, mostly forested and sparsely populated

Stream character \& type: .

Streambed material: Gravel and boulders

Discharge Data (cfs): $\quad Q_{2.33} \underline{\mathbf{4 0 0}}$

$\mathrm{Q}_{50} \mathbf{1 2 5 0}$

$\mathrm{Q}_{10} \frac{\mathbf{7 7 5}}{\mathbf{1 5 0 0}}$

$\mathrm{Q}_{25}$

$\mathrm{Q}_{500}$

Record flood date (MM /DD/YY): - $/$ - $/$ -

Water surface elevation $(f t):-$

Estimated Discharge (cfs):

Velocity at $\mathrm{Q}-$ $(\mathrm{ft} / \mathrm{s}):$

Ice conditions (Heavy, Moderate, Light) : -

Debris (Heavy, Moderate, Light):

The stage increases to maximum highwater elevation (Rapidly, Not rapidly):

The stream response is (Flashy, Not flashy):

Describe any significant site conditions upstream or downstream that may influence the stream's stage: -

Watershed storage area (in percent):

The watershed storage area is: - _ (1-mainly at the headwaters; 2- uniformly distributed; 3-immediatly upstream oi the site)

Water Surface Elevation Estimates for Existing Structure:

\begin{tabular}{|l|c|c|c|l|l|}
\hline Peak discharge frequency & $Q_{2.33}$ & $Q_{10}$ & $Q_{25}$ & $Q_{50}$ & $Q_{100}$ \\
Water surface elevation $(f t))$ & $\mathbf{9 4 6 . 1 1}$ & $\mathbf{9 4 7 . 0 9}$ & & & \\
Velocity $(f t / s e c)$ & $\mathbf{9 4 7 . 6 4}$ & $\mathbf{9 4 8 . 2 1}$ & $\mathbf{9 4 9 . 2 8}$ & - & - \\
\hline
\end{tabular}

Long term stream bed changes: -

Is the roadway overtopped below the $\mathrm{Q}_{100}$ ? (Yes, No, Unknown):

Frequency: -

Relief Elevation $(f t)$ :

Discharge over roadway at $Q_{100}\left(f t^{3} / \mathrm{sec}\right)$ :

Are there other structures nearby? (Yes, No, Unknown): If No or Unknown, type ctrl-n os Upstream distance (miles): Town: Year Built: $\mathbf{Y}$

Highway No. : .04

Clear span (ft): 1925 Structure No. : Hun- Structure Type: tington Clear Height (ft): $\underline{\text { TH22 }}$ Full Waterway $\left(f^{2}\right): \underline{\mathbf{3 0}}$ 
Downstream distance (miles):

Town: beam

Year Built: 26

Highway No. : 10

Structure No. : 260

Structure Type:

.45

Clear span (ft): $\underline{\text { Hun- }}$ Clear Height $(f t):$ ting- Full Waterway $\left(f t^{2}\right): \underline{\text { ton }}$

Comments:

1925

TH22

32

I-beam

35

\section{USGS Watershed Data}

Watershed Hydrographic Data

Drainage area $(D A)$

Watershed storage (ST) $\mathrm{mi}^{2}$

Lake/pond/swamp area

0 $\mathrm{mi}^{2}$

Bridge site elevation 1050 $\mathrm{ft}$ $\%$

Main channel length $\mathbf{2 . 9 5 6}$ mi

$10 \%$ channel length elevation 1140 $\mathrm{ft} \quad 85 \%$ channel length elevation $\mathrm{ft}$

Main channel slope (S) 793.86 $\mathrm{ft} / \mathrm{mi}$

Watershed Precipitation Data

Average site precipitation in Average headwater precipitation in

Maximum 2yr-24hr precipitation event $(124,2)$ in

Average seasonal snowfall (Sn) $\mathrm{ft}$ 


\section{Bridge Plan Data}

Are plans available? $\underline{\mathbf{1 0}}$ If no, type ctrl-n pl Date issued for construction (MM/YYYY): $\underline{\mathbf{3 5}} / \underline{\mathbf{0}}$ Project Number the right end of the abutMinimum channel bed elevation:

Low superstructure elevation: USLAB starts DSLAB under USRAB beam DSRAB 2 , is $3 /$ Benchmark location description: 8 " at the top, and $1 / 8$ " at the bottom. The abutments could possibly be concrete faced laid up stone. There are numerous large boulders in the US and DS channel and along embankments, with areas of erosion from past flooding.

Reference Point (MSL, Arbitrary, Other): Datum (NAD27, NAD83, Other): $\mathbf{N}$

Foundation Type: (1-Spreadfooting; 2-Pile; 3- Gravity; 4-Unknown)

If 1: Footing Thickness _ _ Footing bottom elevation: -

If 2: Pile Type: (1-Wood; 2-Steel or metal; 3-Concrete) Approximate pile driven length: -

If 3: Footing bottom elevation:

Is boring information available? If no, type ctrl-n bi Number of borings taken:

Foundation Material Type: No (1-regolith, 2-bedrock, 3-unknown)

Briefly describe material at foundation bottom elevation or around piles: benchmark information.

Comments:

4

$-$

$-$

-

$-$ 


\section{Cross-sectional Data}

Is cross-sectional data available? $\mathbf{N}$

If no, type ctrl-n xs

Source (FEMA, VTAOT, Other)? -

Comments: 3

No foundation material information is available.

\begin{tabular}{|l|l|l|l|l|l|l|l|l|l|l|l|}
\hline Station & & plan & & VTA & tion & The & vatio & vey & repo & The & lengt \\
\hline Feature & & s & & OT & is the & low & n is & log & rt on & low & h \\
\hline $\begin{array}{l}\text { Low cord } \\
\text { elevation }\end{array}$ & & avail & & This & upst & chor & from & done & 06/ & chor & data \\
\hline $\begin{array}{l}\text { Bed } \\
\text { elevation }\end{array}$ & & able. & & cross & ream & d & the & for & $26 /$ & d to & is \\
\hline $\begin{array}{l}\text { Low cord } \\
\text { bed length }\end{array}$ & No & & Y & -sec- & face. & ele- & sur- & this & 96. & bed & from \\
\hline Station & the & to a & repo & $\mathbf{9 5 .}$ & done & $\mathbf{0}$ & 4 & 10 & 16 & 28 & - \\
\hline Feature & sketc & brid & rt & The & on & LAB & - & - & - & RAB & - \\
\hline $\begin{array}{l}\text { Low cord } \\
\text { elevation }\end{array}$ & h & ge & date & sketc & $11 /$ & 496.7 & - & - & - & 496.2 & - \\
\hline $\begin{array}{l}\text { Bed } \\
\text { elevation }\end{array}$ & attac & inspe & d 07/ & h & $\mathbf{0 3 /}$ & 490.1 & - & - & - & 491.2 & - \\
\hline $\begin{array}{l}\text { Low cord to } \\
\text { bed length }\end{array}$ & hed & ction & $\mathbf{1 7 /}$ & was & 93. & 6.6 & 7.4 & 6.7 & 7.1 & 5.0 & - \\
\hline
\end{tabular}

Source (FEMA, VTAOT, Other)?

Comments: -

\begin{tabular}{|l|l|l|l|l|l|l|l|l|l|l|l|}
\hline Station & - & - & - & - & - & - & - & - & - & - & - \\
\hline Feature & - & - & - & - & - & - & - & - & - & - & - \\
\hline $\begin{array}{l}\text { Low cord } \\
\text { elevation }\end{array}$ & - & - & - & - & - & - & - & - & - & - & - \\
\hline $\begin{array}{l}\text { Bed } \\
\text { elevation }\end{array}$ & - & - & - & - & - & - & - & - & - & - & - \\
\hline $\begin{array}{l}\text { Low cord to } \\
\text { bed length }\end{array}$ & - & - & - & - & - & - & - & - & - & - & - \\
\hline Station & - & - & - & - & - & - & - & - & - & - & - \\
\hline Feature & - & - & - & - & - & - & - & - & - & - & - \\
\hline $\begin{array}{l}\text { Low cord } \\
\text { elevation }\end{array}$ & - & - & - & - & - & - & - & - & - & - & - \\
\hline $\begin{array}{l}\text { Bed } \\
\text { elevation }\end{array}$ & - & - & - & - & - & - & - & - & - & - & - \\
\hline $\begin{array}{l}\text { Low cord to } \\
\text { bed length }\end{array}$ & - & - & - & - & & - & - & - & - & - & - \\
\hline
\end{tabular}




\section{APPENDIX E: \\ LEVEL I DATA FORM}


U. S. Geological Survey

Bridge Field Data Collection and Processing Form

Qa/Qc Check by: RLB Date: 7/12/97

\section{Structure Number}

\section{A. General Location Descriptive}

1. Data collected by (First Initial, Full last name) $\mathbf{J}$. DEGNAN

2. Highway District Number $\mathbf{0 5}$

County Chittenden (007)

Waterway (I - 6) Brush Brook

Route Number $\mathbf{C 3 0 2 2}$
Mile marker 0000

Town Huntington (34600)

Road Name -

Hydrologic Unit Code: $\mathbf{0 2 0 1 0 0 0 3}$

3. Descriptive comments:

This is a steel I-beam type bridge with a wooden deck located 1 mile from the junction with TH 21. There are houses on the overbanks. The bridge is located near an intersection and a sign indicates that this is the road to Camel's Hump Hiking Trails.

\section{B. Bridge Deck Observations}
4. Surface cover... LBUS 6
RBUS 6
LBDS 6
RBDS 6
Overall 6

(2b us,ds,lb,rb: 1- Urban; 2- Suburban; 3- Row crops; 4- Pasture; 5- Shrub- and brushland; 6- Forest; 7- Wetland)
5. Ambient water surface... US 2
UB 2
DS 2
(1- pool; 2- riffle)

6. Bridge structure type 1 (1- single span; 2- multiple span; 3- single arch; 4- multiple arch; 5-cylindrical culvert; 6- box culvert; or 7- other)
7. Bridge length $\mathbf{3 4}$
(feet)
Span length $\underline{\mathbf{3 0}}$
(feet)
Bridge width 15.8 (feet)

\section{Road approach to bridge:}
8. LB 2
RB 2
( 0 even, 1- lower, 2- higher)
9. LB_
RB $\underline{2}$
(1-Paved, 2- Not paved)

10. Embankment slope (run / rise in feet / foot)

US left

\begin{tabular}{|c|c|c|c|}
\hline \multicolumn{2}{|c|}{ Protection } & \multirow{2}{*}{ 13.Erosion } & \multirow{2}{*}{ 14.Severity } \\
\hline 11.Type & 12.Cond. & & \\
\hline 1 & & 1 & 1 \\
\hline
\end{tabular}

LBUS

RBUS

RBDS

LBDS

\begin{tabular}{l}
1 \\
\hline 0 \\
\hline 0
\end{tabular}

\begin{tabular}{l}
$\frac{3}{1}$ \\
\hline- \\
\hline
\end{tabular}

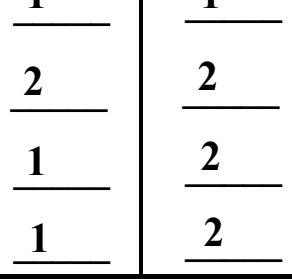

Bank protection types: 0 - none; 1 - $<12$ inches;

2- < 36 inches; 3- $<48$ inches;

4- < 60 inches; 5- wall / artificial levee

Bank protection conditions: 1- good; 2- slumped;

3- eroded; 4- failed

Erosion: 0 - none; 1- channel erosion; 2 -

road wash; 3- both; 4- other

Erosion Severity: 0 - none; 1- slight; 2- moderate; 3- severe

\section{Channel approach to bridge (BF):}

15. Angle of approach: $\mathbf{2 0}$

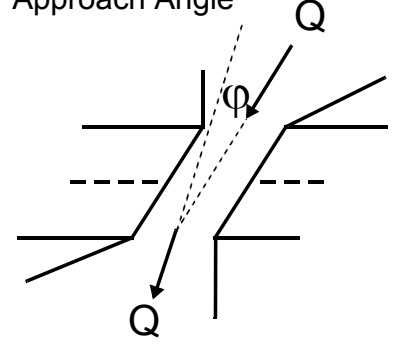

17. Channel impact zone 1:

Where? RB (LB, RB)

Range? 40 feet US

Channel impact zone 2:

Where? LB $(L B, R B)$

Range? $\underline{\mathbf{0}}$ feet $\underline{\mathbf{D S}}$

Impact Severity: 0- none to very slight; 1- Slight; 2- Moderate; 3- Severe
16. Bridge skew: 15 Bridge Skew Angle

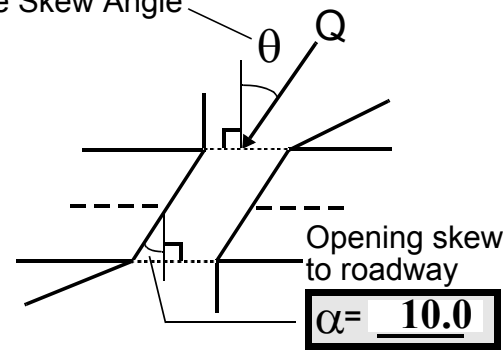

\section{Exist? $\mathbf{Y}(\mathrm{Y}$ or $N)$}

Severity 2

(US, UB, DS) to 0 feet $\mathbf{U S}$

Exist? $\mathbf{Y}(Y$ or $N)$

Severity 1

BB, DS) to $\underline{\mathbf{3 0}}$ feet $\underline{\mathbf{D S}}$ 
18. Bridge Type: 1a

1a- Vertical abutments with wingwalls

1 b- Vertical abutments without wingwalls

2- Vertical abutments and wingwalls, sloping embankment

Wingwalls parallel to abut. face

3- Spill through abutments

4- Sloping embankment, vertical wingwalls and abutments

1a with wingwalls

Wingwall angle less than $90^{\circ}$.

19. Bridge Deck Comments (surface cover variations, measured bridge and span lengths, bridge type variations, approach overflow width, etc.)

7. Values are from the VT AOT database.

18. There are wingwalls on the left side and they are almost parallel to the road.

There are no wingwalls on the right side of the bridge.

\section{Upstream Channel Assessment}

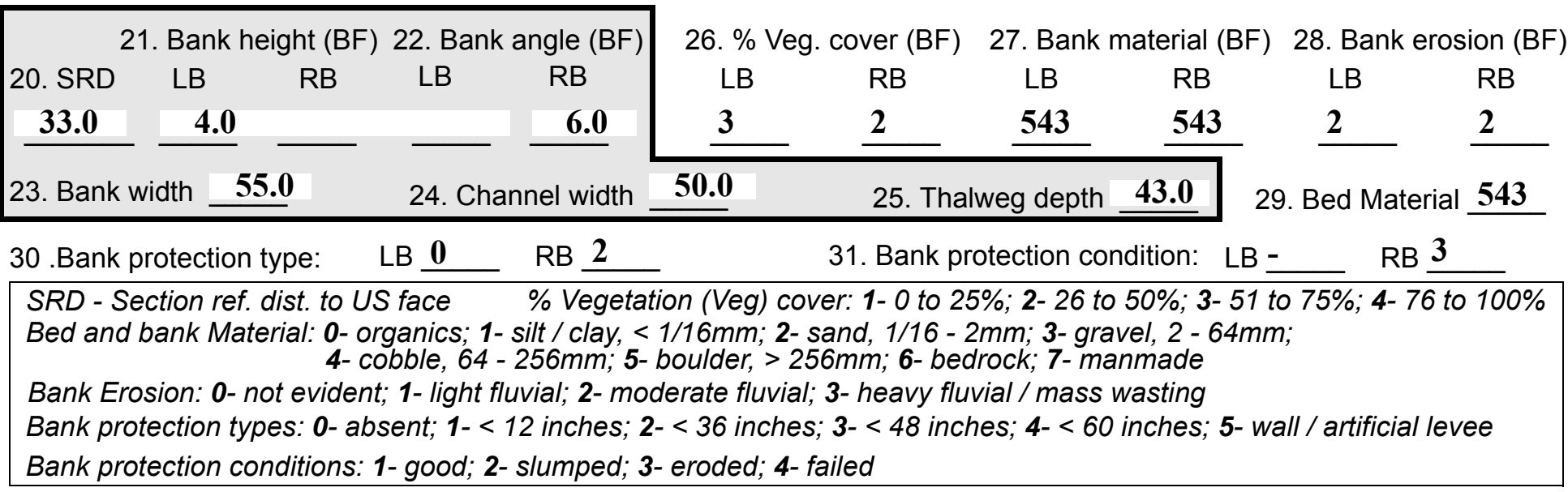

32. Comments (bank material variation, minor inflows, protection extent, etc.):

30. The right bank protection extends from $0 \mathrm{ft}$ US to $24 \mathrm{ft}$ US where it is eroded by road wash. 
36. Point bar extent: 105 feet $\underline{\text { US }}$ (US, UB) to $\underline{\mathbf{7 0}}$ feet $\underline{\mathrm{US}}$ (US, UB, DS) positioned $\underline{\mathbf{8 0}} \%$ LB to $\underline{\mathbf{1 0 0}} \%$

37. Material: $\mathbf{5 4 3}$

38. Point or side bar comments (Circle Point or Side; Note additional bars, material variation, status, etc.):

39. Is a cut-bank present? $\mathbf{Y}$ (Y or if $N$ type ctrl-n cb)

40. Where? $\mathbf{R B} \quad(L B$ or $R B)$

41. Mid-bank distance: $\mathbf{4 5}$

42. Cut bank extent: $\mathbf{5 0}$

\section{(US,} feet $\underline{\mathbf{U S}}$ (US, UB, DS)

43. Bank damage: 1

(1- eroded and/or creep; 2- slip failure; 3- block failure)

44. Cut bank comments (eg. additional cut banks, protection condition, etc.):

Both banks have exposed tree roots.

45. Is channel scour present? $\mathbf{N}$ ( $Y$ or if $N$ type ctrl-n cs)

47. Scour dimensions: Length Width -

Depth : -

46. Mid-scour distance:

48. Scour comments (eg. additional scour areas, local scouring process, etc.):

NO CHANNEL SCOUR

49. Are there major confluences? $\mathbf{N}$

51. Confluence 1: Distance Confluence 2: Distance -
52. Enters on -

Enters on -
( $Y$ or if $N$ type ctrl-n $m c$ ) ( $L B$ or $R B)$ ( $L B$ or $R B)$

54. Confluence comments (eg. confluence name):

NO MAJOR CONFLUENCES. On the left bank a dry channel rejoins the stream at the US left wingwall.

There is a culvert on the right bank $65 \mathrm{ft}$ US.

\section{Under Bridge Channel Assessment}

55. Channel restraint (BF)? LB 2

\begin{tabular}{|ccccc|}
\hline \multicolumn{2}{|c}{ 56. Height (BF) } & \multicolumn{3}{c|}{57 Angle (BF) } \\
LB & RB & LB & RB \\
$\mathbf{3 1 . 0}$ & & & $\mathbf{1 . 0}$ & \\
\hline
\end{tabular}

58. Bank width (BF) (1- natural bank; 2- abutment; 3- artificial levee)

Bed and bank Material: 0- organics; 1- silt / clay, < 1/16mm; 2- sand, 1/16 - 2mm; 3- gravel, 2 - 64mm; 4- cobble, 64 - 256mm; 5- boulder, > 256mm; 6- bedrock; 7- manmade

\begin{tabular}{|c|c|c|c|}
\hline \multicolumn{2}{|c|}{ 61. Material (BF) } & \multicolumn{2}{|c|}{ 62. Erosion (BF) } \\
\hline LB & $\mathrm{RB}$ & LB & $\mathrm{RB}$ \\
\hline 2 & 7 & 7 & - \\
\hline
\end{tabular}

60. Thalweg depth $\mathbf{9 0 . 0}$ (1-perennial; 2- ephemeral) (1- perennial; 2- ephemeral)

Bank Erosion: 0- not evident; 1- light fluvial; 2- moderate fluvial; 3- heavy fluvial / mass wasting

64. Comments (bank material variation, minor inflows, protection extent, etc.):

543 
65. Debris and Ice Is there debris accumulation?

(Yor $N)$ 66. Where? $\underline{Y}$

(1- Upstream; 2- At bridge; 3- Both)

67. Debris Potential $\underline{3}$

( 1- Low; 2- Moderate; 3- High)

68. Capture Efficiency 2

(1-Low; 2- Moderate; 3- High)

69. Is there evidence of ice build-up? 2

Ice Blockage Potential $\underline{Y}$

(1-Low; 2-Moderate; 3- High)

70. Debris and Ice Comments:

2

66. There are logs and branches in the channel US and DS.

69. There is scarring on the trees due to ice.

\begin{tabular}{|l|c|c|c|c|c|c|c|c|}
\hline Abutments & $\begin{array}{c}\text { 71. Attack } \\
\angle \text { (BF) }\end{array}$ & $\begin{array}{c}\text { 72. Slope } \angle \\
\text { (Qmax) }\end{array}$ & $\begin{array}{c}\text { 73. Toe } \\
\text { loc. (BF) }\end{array}$ & $\begin{array}{c}\text { 74. Scour } \\
\text { Condition }\end{array}$ & $\begin{array}{c}\text { 75. Scour } \\
\text { depth }\end{array}$ & $\begin{array}{c}\text { 76. Exposure } \\
\text { depth }\end{array}$ & 77. Material & 78. Length \\
\hline LABUT & & $\mathbf{5}$ & $\mathbf{9 0}$ & $\mathbf{2}$ & $\mathbf{0}$ & - & - & $\mathbf{9 0 . 0}$ \\
\hline RABUT & $\mathbf{1}$ & - & $\mathbf{9 0}$ & & & $\mathbf{2}$ & $\mathbf{0}$ & $\mathbf{3 0 . 5}$ \\
\hline
\end{tabular}

Pushed: $L B$ or RB

Toe Location (Loc.): 0- even, 1- set back, 2- protrudes

Scour cond.: 0- not evident; 1- evident (comment); 2- footing exposed; 3-undermined footing; 4- piling exposed; 5- settled; 6- failed

Materials: 1- Concrete; 2- Stone masonry or drywall; 3- steel or metal; 4- wood

79. Abutment comments (eg. undermined penetration, unusual scour processes, debris, etc.):

$-$

1

74. There is some undermining of the left abutment.

80. Wingwalls:

Exist? Material? Scour Scour Exposure Angle? Length? Condition? depth? depth?

USLWW:

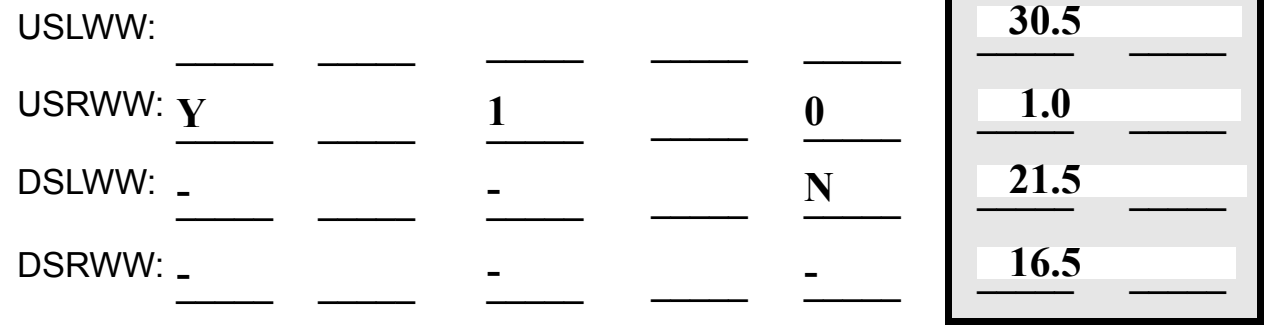

Wingwall materials: 1- Concrete; 2- Stone masonry or drywall; 3- steel or metal; 4- wood

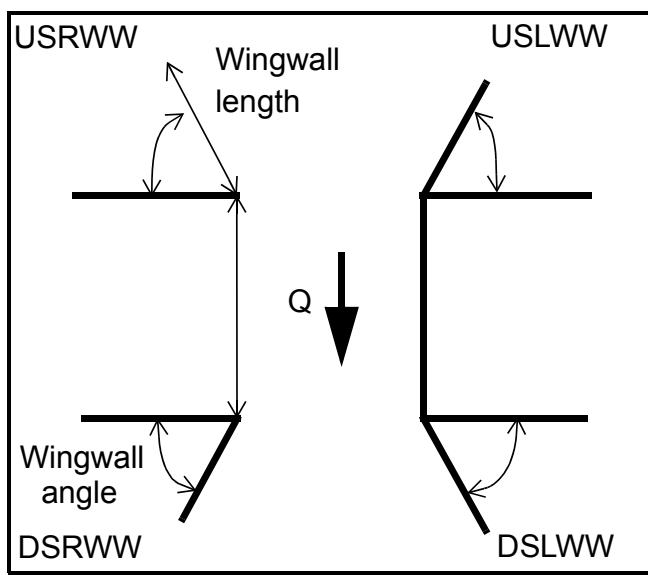

82. Bank / Bridge Protection:

\begin{tabular}{|l|l|l|l|l|l|l|l|l|}
\hline Location & USLWW & USRWW & LABUT & RABUT & LB & RB & DSLWW & DSRWW \\
\hline Type & - & $\mathbf{0}$ & $\mathbf{N}$ & - & - & - & - & - \\
\hline Condition & $\mathbf{Y}$ & - & - & - & - & - & - & - \\
\hline Extent & $\mathbf{1}$ & - & - & $\mathbf{0}$ & - & $\mathbf{0}$ & $\mathbf{0}$ & - \\
\hline
\end{tabular}

Bank / Bridge protection types: 0- absent; 1- < 12 inches; 2- < 36 inches; 3- < 48 inches; 4- < 60 inches; 
83. Wingwall and protection comments (eg. undermined penetration, unusual scour processes, etc.):

$-$

$-$

$-$

$-$

0

$-$

$-$

$-$

$-$

\section{Piers:}

84. Are there piers? $\mathbf{8 0 .}$ ( $Y$ or if $N$ type ctrl-n pr)

\begin{tabular}{|l|c|l|c|c|c|c|c|}
\hline \multirow{2}{*}{$\begin{array}{l}85 . \\
\text { Pier no. }\end{array}$} & \multicolumn{3}{|c|}{ width (w) feet } & \multicolumn{3}{c|}{ elevation (e) feet } \\
\cline { 2 - 9 } & w1 & w2 & w3 & e@w1 & e@w2 & e@w3 \\
\hline Pier 1 & $\mathbf{5 . 0}$ & - & $\mathbf{5 . 0}$ & $\mathbf{6 . 0}$ & - & $\mathbf{4 . 5}$ \\
\hline Pier 2 & - & - & - & - & - & - \\
\hline Pier 3 & - & - & - & - & - & - \\
\hline Pier 4 & - & - & - & - & - & - \\
\hline
\end{tabular}

\begin{tabular}{|l|l|l|l|l|}
\hline Level 1 Pier Descr. & \multicolumn{1}{|c|}{1} & \multicolumn{1}{|c|}{2} & 3 & 4 \\
\hline 86. Location (BF) & A & end of & & - \\
\hline 87. Type & scou & the & & - \\
\hline 88. Material & r & left & & - \\
\hline 89. Shape & hole & abut & & - \\
\hline 90. Inclined? & was & ment & N & - \\
\hline 91. Attack $\angle$ (BF) & obse & - & - & - \\
\hline 92. Pushed & rved & & - & - \\
\hline 93. Length (feet) & - & - & - & - \\
\hline 94. \# of piles & at & & - & - \\
\hline 95. Cross-members & the & & - & - \\
\hline 96. Scour Condition & dow & & - & - \\
\hline 97. Scour depth & nstre & & - & - \\
\hline 98. Exposure depth & am & & - & - \\
\hline
\end{tabular}

LFP, LTB, LB, MCL, MCM, MCR, RB, RTB, RFP

1- Solid pier, 2-column, 3- bent

1-Wood; 2- concrete; 3- metal; 4- stone

1- Round; 2- Square; 3- Pointed

Y-yes; $N$ - no

$L B$ or $R B$

0- none; 1- laterals; 2- diagonals; 3- both

0- not evident; 1- evident (comment);

2- footing exposed; 3- piling exposed;

4- undermined footing; 5 - settled; 6 - failed 
99. Pier comments (eg. undermined penetration, protection and protection extent, unusual scour processes, etc.):

-
-
-
-
-
-
-
-
-
-

100.

\section{E. Downstream Channel Assessment}

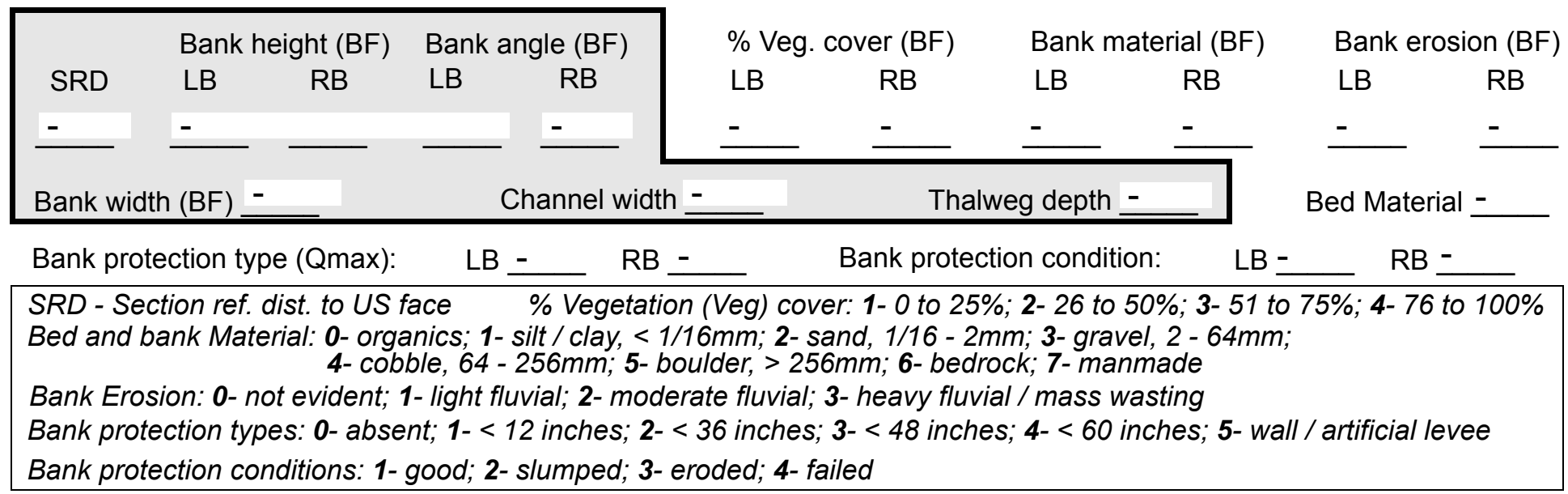

Comments (eg. bank material variation, minor inflows, protection extent, etc.):

$-$

$-$

$-$

$-$

$-$

$-$

$-$

$-$

NO PIERS

101. Is a drop structure present? ( $Y$ or $N$, if $N$ type ctrl-n $d s)$

102. Distance: - feet

103. Drop: __ feet 104. Structure material: (1- steel sheet pile; 2- wood pile; 3- concrete; 4- other)

105. Drop structure comments (eg. downstream scour depth): 
Point bar extent: $\underline{\mathbf{0}}$ feet (US, UB, DS) to feet (US, UB, DS) positioned \%LB to $\%$ RB

Material:

Point or side bar comments (Circle Point or Side; note additional bars, material variation, status, etc.):

Is a cut-bank present?

Cut bank extent: feet (Y or if $N$ type ctrl-n cb) Where? (LB or $R B)$ feet (US, UB, DS)

Bank damage: $\mathbf{N}$ (1- eroded and/or creep; 2- slip failure; 3- block failure)

Cut bank comments (eg. additional cut banks, protection condition, etc.):

$-$

NO DROP STRUCTURE

Is channel scour present? (Y or if $N$ type ctrl-n cs)

Mid-scour distance:

Scour dimensions: Length Width $\underline{\mathbf{Y}}$ Depth: 0 DS

Positioned $\underline{\mathbf{1 5}} \%$ LB to $\underline{\mathbf{0}} \% \mathrm{RB}$

Scour comments (eg. additional scour areas, local scouring process, etc.):

US

17

DS

40

Are there major confluences? 10 (Y or if $N$ type ctrl-n $m c)$

Confluence 1: Distance $\mathbf{4 5 3}$

Confluence 2: Distance anot

Enters on The (LB or RB)

Enters on her (LB or RB)

How many? 0

Type re is (1-perennial; 2- ephemeral)

Type poin (1- perennial; 2- ephemeral)

Confluence comments (eg. confluence name):

$t$ bar on the right bank extending from $48 \mathrm{ft}$ DS to $90 \mathrm{ft}$ DS. The mid-bar is at $60 \mathrm{ft}$ DS with a width of $7 \mathrm{ft}$. It consists of mostly gravel and some cobbles and boulders.

\section{F. Geomorphic Channel Assessment}

107. Stage of reach evolution

1- Constructed

2- Stable

3- Aggraded

4- Degraded

5- Laterally unstable

6- Vertically and laterally unstable 
108. Evolution comments (Channel evolution not considering bridge effects; See HEC-20, Figure 1 for geomorphic descriptors):

Y

LB

10

0

DS

40

DS

2

$-$ 


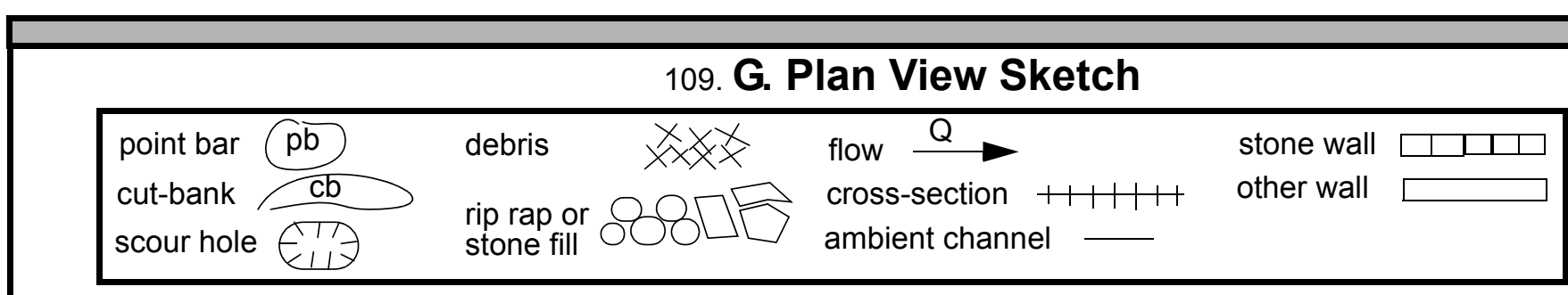


APPENDIX F:

SCOUR COMPUTATIONS 
SCOUR COMPUTATIONS

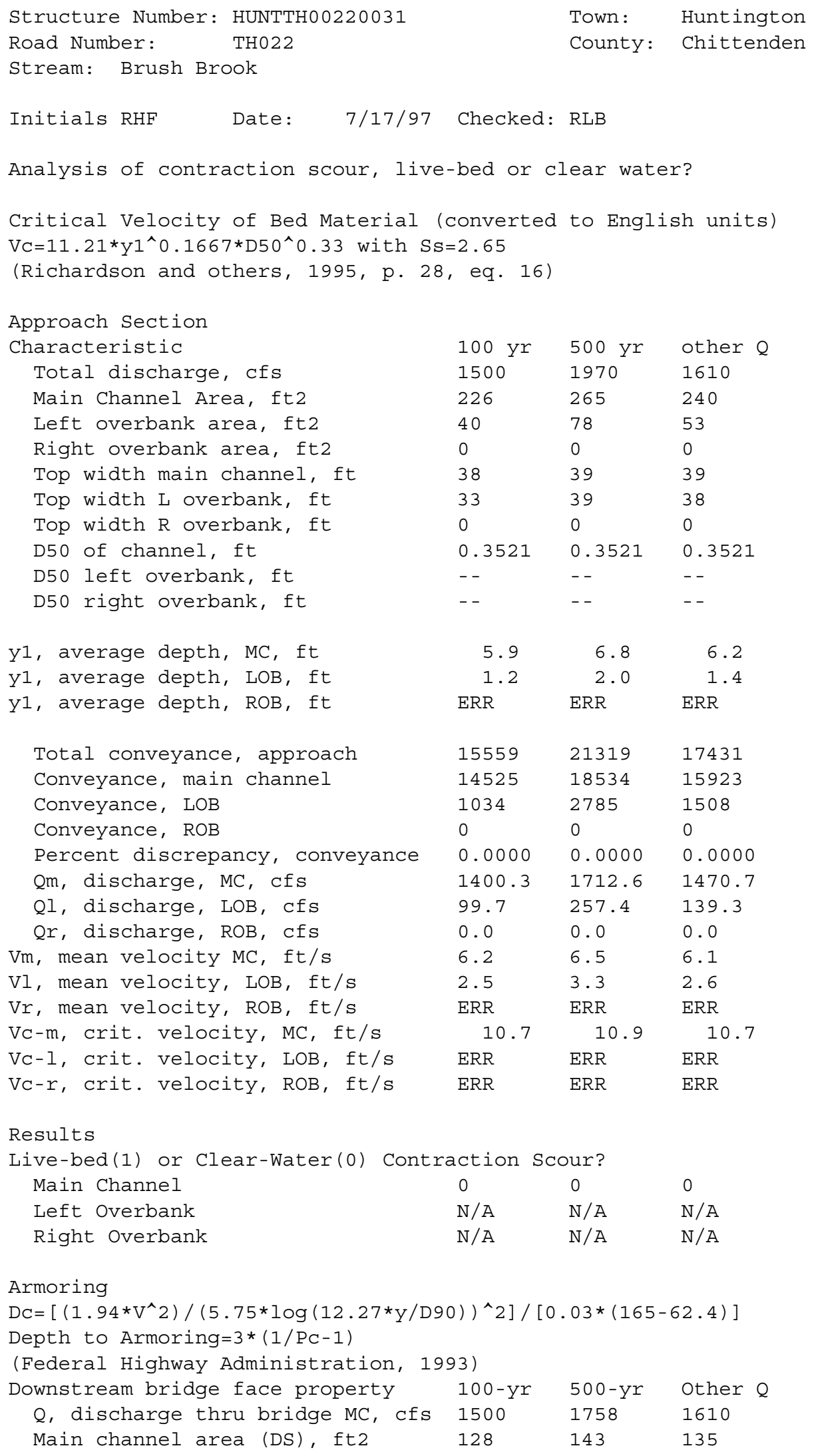




$\begin{array}{llll}\text { Main channel width (normal), ft } & 30.7 & 30.73 & 30.7 \\ \text { Cum. width of piers, ft } & 0.0 & 0.0 & 0.0 \\ \text { Adj. main channel width, ft } & 30.7 & 30.7 & 30.7 \\ \text { D90, ft } & 2.0436 & 2.0436 & 2.0436 \\ \text { D95, ft } & 3.3900 & 3.3900 & 3.3900 \\ \text { Dc, critical grain size, ft } & 1.3393 & 1.3775 & 1.3423 \\ \text { PC, Decimal percent coarser than Dc } 0.169 & 0.163 & 0.169 \\ & & & \\ \text { Depth to armoring, ft } & 19.74 & 21.22 & 19.85 \\ \text { Clear Water Contraction Scour in MAIN CHANNEL } & \end{array}$

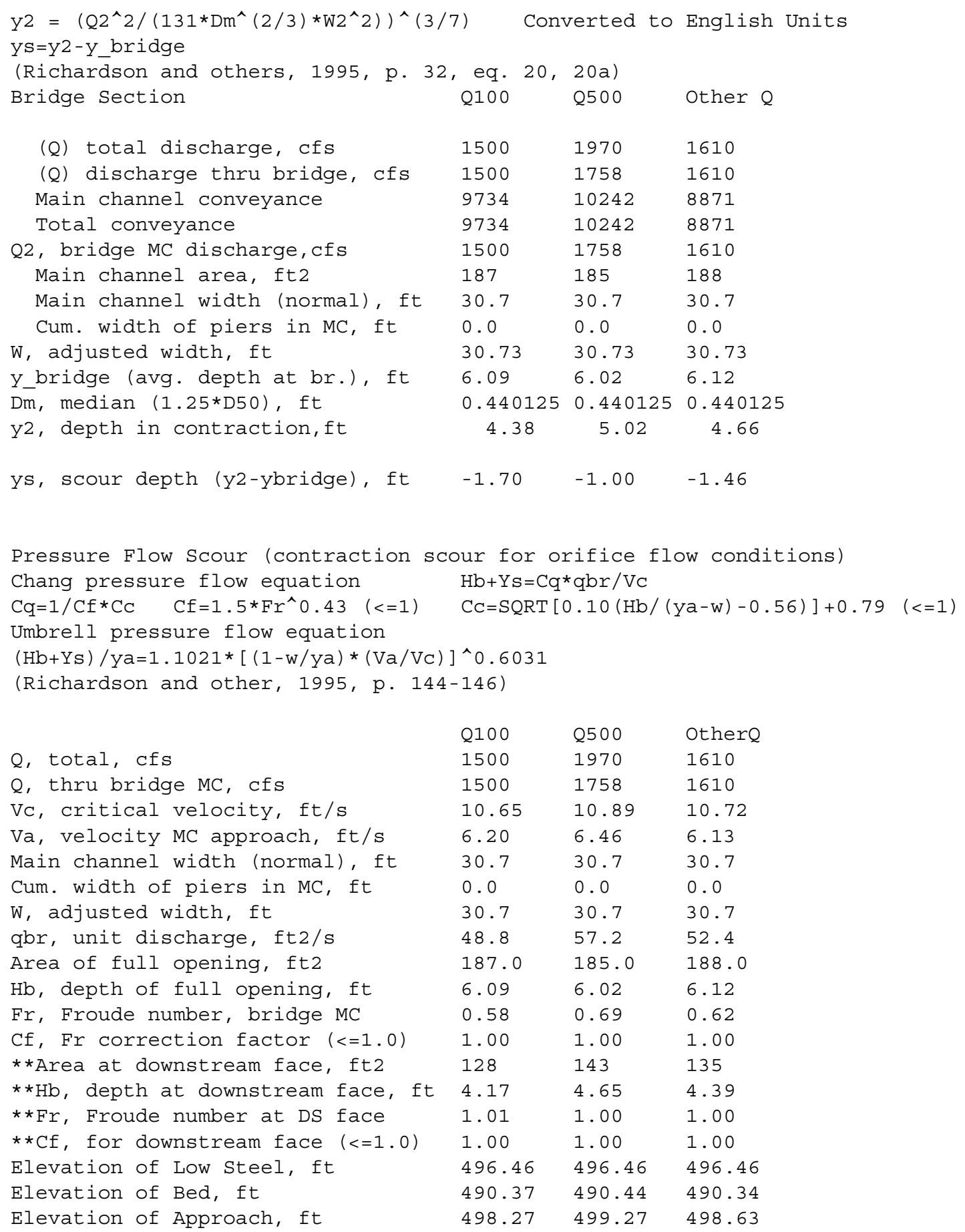




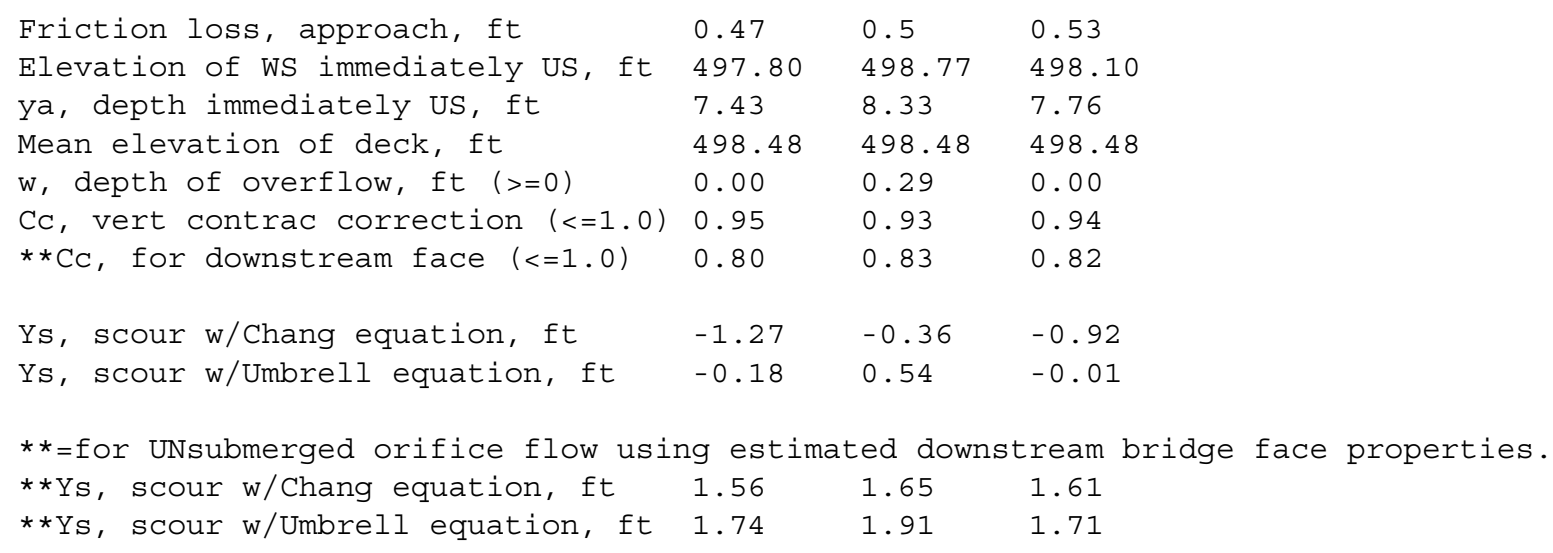

In UNsubmerged orifice flow, an adjusted scour depth using the Laursen equation results and the estimated downstream bridge face properties can also be computed (ys=y2-ybridgeDs)

$\begin{array}{lllll}\text { Y2, from Laursen's equation, ft } & 4.38 & 5.02 & 4.66 \\ \text { WSEL at downstream face, ft } & 494.51 & 495.00 & 494.73 \\ \text { Depth at downstream face, ft } & 4.17 & 4.65 & 4.39 \\ \text {, depth of scour (Laursen), ft } & 0.22 & 0.37 & 0.26\end{array}$

Abutment Scour

Froehlich's Abutment Scour

$\mathrm{Ys} / \mathrm{Y} 1=2.27 * \mathrm{~K} 1 * \mathrm{~K} 2 *\left(\mathrm{a}^{\prime} / \mathrm{Y} 1\right)^{\wedge} 0.43 * \mathrm{Fr} 1^{\wedge} 0.61+1$

(Richardson and others, 1995, p. 48, eq. 28)

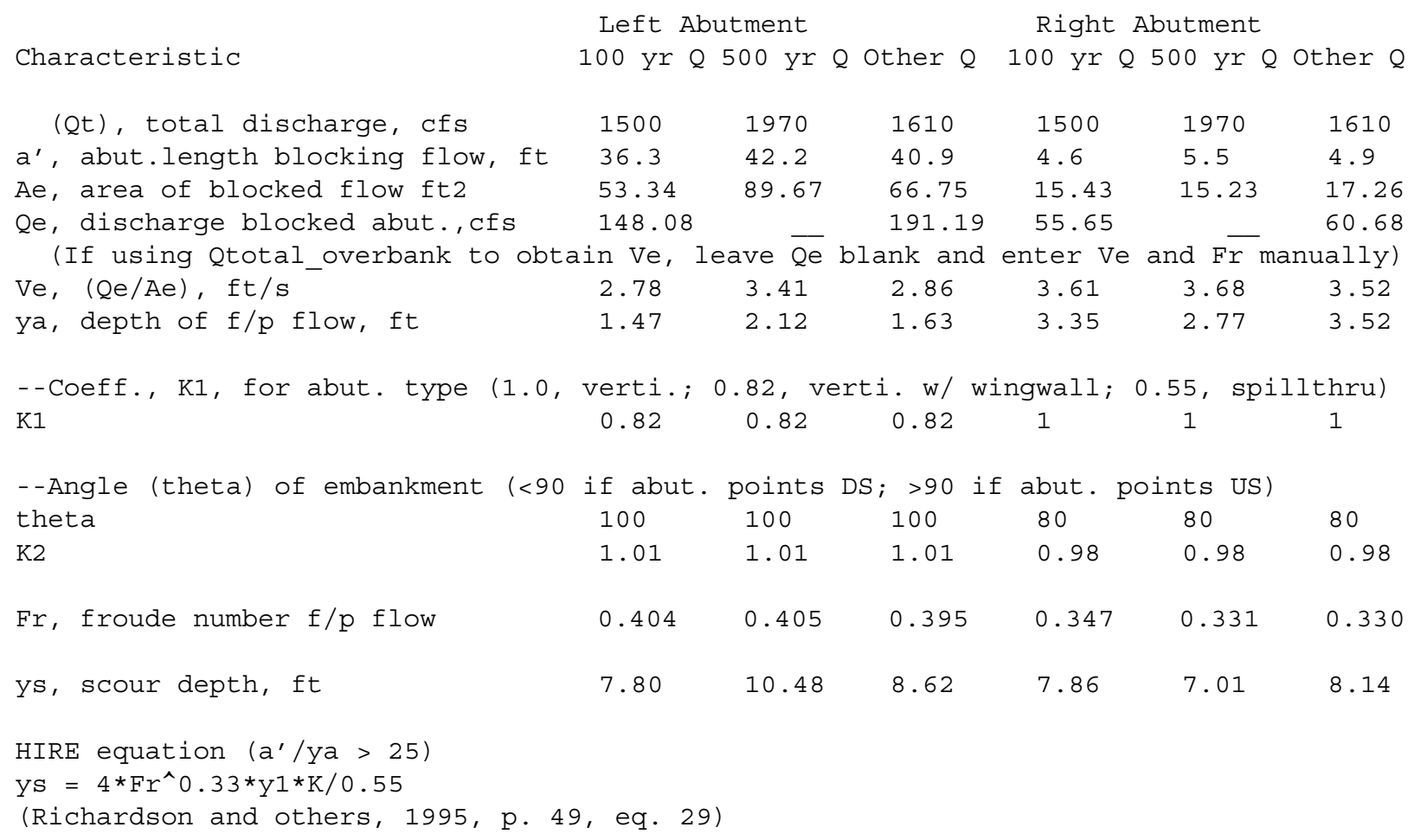




\begin{tabular}{|c|c|c|c|c|c|c|}
\hline$a^{\prime}$ (abut length blocked, ft) & 36.3 & 42.2 & 40.9 & 4.6 & 5.5 & 4.9 \\
\hline y1 (depth f/p flow, ft) & 1.47 & 2.12 & 1.63 & 3.35 & 2.77 & 3.52 \\
\hline$a^{\prime} / y^{1}$ & 24.70 & 19.86 & 25.06 & 1.37 & 1.99 & 1.39 \\
\hline Skew correction (p. 49, fig. 16) & 1.02 & 1.02 & 1.02 & 0.98 & 0.98 & 0.98 \\
\hline Froude no. f/p flow & 0.40 & 0.41 & 0.40 & 0.35 & 0.39 & 0.33 \\
\hline \multirow{4}{*}{$\begin{array}{l}\text { Ys w/ corr. factor } \mathrm{Kl} / 0.55: \\
\text { vertical } \\
\text { vertical w/ ww's } \\
\text { spill-through }\end{array}$} & & & & & & \\
\hline & ERR & ERR & 8.93 & ERR & ERR & ERR \\
\hline & ERR & $\mathrm{ERR}$ & 7.32 & ERR & ERR & ERR \\
\hline & ERR & ERR & 4.91 & ERR & ERR & ERR \\
\hline \multicolumn{7}{|l|}{ Abutment riprap Sizing } \\
\hline \multirow{2}{*}{\multicolumn{7}{|c|}{$\begin{array}{l}\text { Isbash Relationship } \\
\mathrm{D} 50=\mathrm{Y}^{*} \mathrm{~K} * \mathrm{Fr} \mathbf{r}^{\wedge} /(\mathrm{Ss}-1) \text { and } \mathrm{D} 50=\mathrm{Y}^{*} \mathrm{~K} *\left(\mathrm{Fr} r^{\wedge} 2\right)^{\wedge} 0.14 /(\mathrm{Ss}-1) \\
\text { (Richardson and others, 1995, p112, eq. 81,82) }\end{array}$}} \\
\hline & & & & & & \\
\hline \multicolumn{7}{|c|}{ Downstream Yields most conservative result } \\
\hline Characteristic & Q100 & 2500 & Other $\mathrm{Q}$ & Q100 & Q500 & Other $Q$ \\
\hline Fr, Froude Number & 1 & 1 & 1 & 1 & 1 & 1 \\
\hline$y$, depth of flow in bridge, ft & 4.17 & 4.65 & 4.39 & 4.17 & 4.65 & 4.39 \\
\hline Median Stone Diameter for riprap & : left & utment & & right & abutment, & ft \\
\hline Fr<=0.8 (vertical abut.) & ERR & ERR & ERR & ERR & ERR & ERR \\
\hline Fr>0.8 (vertical abut.) & 1.74 & 1.95 & 1.84 & 1.74 & 1.95 & 1.84 \\
\hline
\end{tabular}

